\title{
Phosphorylation of Nucleosides and Nucleotides with Inorganic Monoimido-cyclo-Triphosphate
}

\author{
Hideko Maeda, Takeshi Chiba, Mitsutomo Tsuhako, and Hirokazu Nakayama* \\ Department of Functional Molecular Chemistry, Kobe Pharmaceutical University; 4-19-1 Motoyamakita-machi, \\ Higashinada-ku, Kobe 658-8558, Japan.
}

Received August 3, 2008; accepted September 23, 2008; published online October 1, 2008

The phosphorylation of nucleosides (adenosine, guanosine, cytidine, and uridine) and nucleotides (adenosine 5'-monophosphate, guanosine 5'-monophosphate, cytidine $5^{\prime}$-monophosphate and uridine $5^{\prime}$-monophosphate) has been achieved using inorganic monoimido-cyclo-triphosphate (MCTP, $\mathrm{Na}_{3} \mathrm{P}_{3} \mathrm{O}_{8} \mathrm{NH}$ ) in aqueous solution. In this reaction, the $2^{\prime}-\mathrm{OH}$ or $3^{\prime}-\mathrm{OH}$ group of the $\beta$-D-ribofuranose unit was phosphorylated and the total yield was more than $30 \%$ and $14 \%$, respectively. The main products were $2^{\prime}$-diphosphoramidophosphononucleoside and 2'-diphosphoramidophosphononucleoside $5^{\prime}$-monophosphate.

Key words phosphorylation; monoimido-cyclo-triphosphate; multinuclear NMR; HPLC

Nucleosides and related organic compounds are usually phosphorylated by phosphoryl chloride, ${ }^{1)}$ polyphosphoric acid $^{2-4)}$ and various organic phosphorus compounds. ${ }^{5-8)} \mathrm{Be}-$ cause phosphorylation with these agents is accompanied by various side reactions, protection of other functional groups is necessary and complicated procedures are typically required.

Sodium cyclo-triphosphate, $\mathrm{Na}_{3} \mathrm{P}_{3} \mathrm{O}_{9}\left(\mathrm{P}_{3 m}\right)$, is a simple and efficient inorganic phosphorylating agent. One of the authors reported the phosphorylation of nucleosides ${ }^{9)}$ and nucleotides ${ }^{10)}$ by $\mathrm{P}_{3 \mathrm{~m}}$. The $2^{\prime}$ - and $3^{\prime}-\mathrm{OH}$ groups of the $\beta$-D-ribofuranosyl unit on nucleosides and nucleotides were selectively phosphorylated in high yield without the need for protection of the other hydroxyl groups. The main phosphorylated products were $2^{\prime}$ - and $3^{\prime}$-monophosphate esters of the nucleosides and nucleotides. We also reported that alkylamines, ${ }^{11)}$ aminoalcohols, ${ }^{12)}$ and carbohydrates ${ }^{13-18)}$ are readily phosphorylated with $\mathrm{P}_{3 \mathrm{~m}}$ to give the corresponding triphosphate derivatives. Unfortunately, phosphorylated carbohydrates are easily decomposed to monophosphate derivatives. ${ }^{9,10,13-18)}$

We have developed new inorganic phosphorylating reagents, imido-cyclo-triphosphates, $\mathrm{Na}_{3} \mathrm{P}_{3} \mathrm{O}_{9-n}(\mathrm{NH})_{n}$. Compared with the $\mathrm{P}-\mathrm{O}-\mathrm{P}$ linkage, the $\mathrm{P}-\mathrm{NH}-\mathrm{P}$ linkage is stable and difficult to hydrolyze. ${ }^{19)}$ We therefore explored the use of imido-cyclo-triphosphates for the phosphorylation of biologically important compounds. Monoimido-cyclo-triphosphate (MCTP), diimido-cyclo-triphosphate (DCTP), and triimidocyclo-triphosphate (TCTP), shown in Fig. 1, were synthesized. Our current interest is to disclose the phosphorylation mechanism by MCTP and DCTP. TCTP did not react even under strict conditions such as $\mathrm{pH} 13$ and $70^{\circ} \mathrm{C}$.

MCTP is a six-membered ring composed of one $\mathrm{P}-\mathrm{NH}-\mathrm{P}$ and two $\mathrm{P}-\mathrm{O}-\mathrm{P}$ linkages. We recently demonstrated that the phosphorylation of methylamine ${ }^{20)}$ and amino acids ${ }^{21)}$ proceeded with MCTP. More recently, we reported that D-glucose, D-glucuronic acid and 2-deoxy-D-glucose reacted with MCTP to form 1- $O$-diphosphoramidophosphono- $\beta$-D-aldoses stereoselectively. ${ }^{22)}$ Organic compounds containing amino or hydroxyl group were easily phosphorylated by MCTP. We also reported that D-glucose and gluco-oligosaccharides reacted with DCTP. ${ }^{23)}$
In the present work, we chose MCTP and first studied the reaction of nucleosides with MCTP in aqueous solution, followed by phosphorylation of nucleotides, in order to synthesize triphosphate derivatives of nucleosides and nucleotides.

\section{Results and Discussion}

Phosphorylation of Adenosine (1), Guanosine (2), Cytidine (3) and Uridine (4) with MCTP Nucleosides used in the present study are shown in Fig. 2. Phosphorylation was carried out essentially according to the previously described

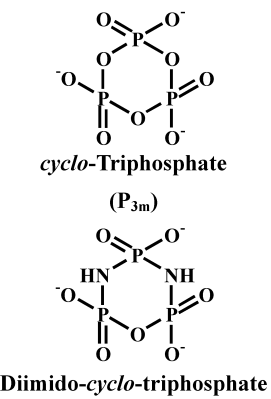

(DCTP)

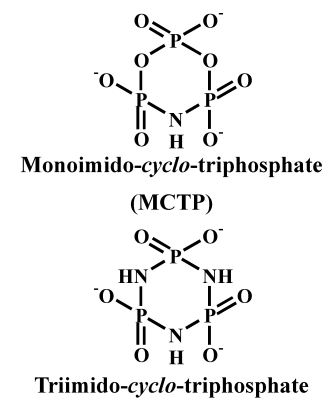

(TCTP)
Fig. 1. Structure of cyclo-Triphosphate $\left(\mathrm{P}_{3 \mathrm{~m}}\right)$, Monoimido-cyclo-Triphosphate (MCTP), Diimido-cyclo-Triphosphate (DCTP), and Triimido-cycloTriphosphate (TCTP)

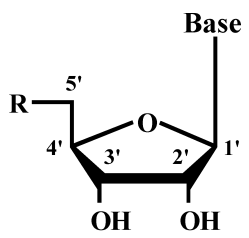

$$
\begin{array}{lll}
1 & \text { Base = adenine } & \mathrm{R}=\mathrm{OH} \\
2 & \text { Base }=\text { guanine } & \mathrm{R}=\mathrm{OH} \\
3 & \text { Base }=\text { cytosine } & \mathrm{R}=\mathrm{OH} \\
4 & \text { Base }=\text { uracil } & \mathrm{R}=\mathrm{OH} \\
13 & \text { Base = adenine } & \mathrm{R}=\mathrm{PO}_{4}{ }^{2-} \\
14 & \text { Base = guanine } & \mathrm{R}=\mathrm{PO}_{4}{ }^{2-} \\
15 & \text { Base }=\text { cytosine } & \mathrm{R}=\mathrm{PO}_{4}{ }^{2-} \\
16 & \text { Base }=\text { uracil } & \mathrm{R}=\mathrm{PO}_{4}{ }^{2-}
\end{array}
$$

Fig. 2. Structure of Nucleosides and Nucleotides Studied in This Work 


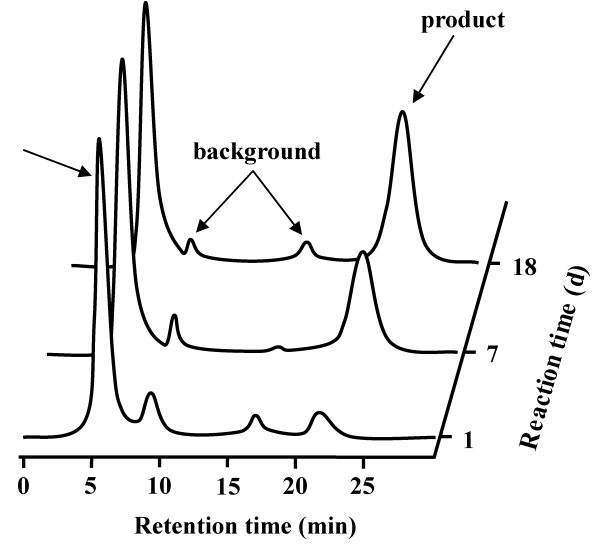

Fig. 3. HPLC Profiles for the Reaction Mixture of 1 and MCTP MCTP : adenosine $(\mathbf{1})=0.4 \mathrm{M}: 0.1 \mathrm{M}, \mathrm{pH} 12$, and $40^{\circ} \mathrm{C}$.

method. ${ }^{20-22)}$ HPLC analysis served as a tool for evaluating the yields of products from their peak area. Figure 3 shows HPLC profiles for the reaction mixture of adenosine (1) $(0.1 \mathrm{M})$ and MCTP $(0.4 \mathrm{M})$ incubated at $\mathrm{pH} 12$ and $40^{\circ} \mathrm{C}$. A peak attributed to the phosphorylated product appeared at a retention time of about $20 \mathrm{~min}$. The other chromatographic peaks were assigned to adenosine and background peaks, respectively. Although, the HPLC profile of the reaction of 1 with MCTP showed a single peak attributable to the reaction product, ${ }^{31} \mathrm{P}-\mathrm{NMR}$ spectra (Fig. 4) showed two imidotriphosphate esters, $\mathbf{5}$ and $\mathbf{6}$, which could not be separated by HPLC. The total yield of $\mathbf{5}$ and $\mathbf{6}$ was $57 \%$ after $18 \mathrm{~d}$ and the compounds remained stable for $50 \mathrm{~d}$ without hydrolysis of the imidotriphosphate esters.

To identify 5 and $\mathbf{6},{ }^{31} \mathrm{P}$ - and ${ }^{1} \mathrm{H}-\mathrm{NMR}$ spectra were measured. In the ${ }^{31} \mathrm{P}-\mathrm{NMR}$ spectra, the peak at $0.3 \mathrm{ppm}$ was assigned to $\mathrm{P}_{\alpha}$ of 5 , and the peak at $1.1 \mathrm{ppm}$ to $\mathrm{P}_{\alpha}$ of $\mathbf{6}$. A previous study indicated that the phosphorylation products of $\mathrm{D}$ glucose derivatives ${ }^{22)}$ with MCTP are diphosphoramidophosphono-D-aldoses with an $-\mathrm{O}-\mathrm{P}_{\alpha}-\mathrm{NH}-\mathrm{P}_{\beta}-$ bond. These products show a characteristic $\mathrm{P}_{\alpha}$ signal at around $0 \mathrm{ppm}$ in their ${ }^{31} \mathrm{P}-\mathrm{NMR}$ spectra. Therefore, the two doublets of doublets at 0.3 and $1.1 \mathrm{ppm}$ in the ${ }^{1} \mathrm{H}$ non-decoupled ${ }^{31} \mathrm{P}-\mathrm{NMR}$ spectrum, which collapsed to two doublets in the ${ }^{1} \mathrm{H}$ decoupled spectrum, exhibited the characteristic peak pattern of $\mathrm{P}_{\alpha}$ similar to those of monoimidotriphosphate derivatives. ${ }^{20-22)}$ The other doublets at -4.8 and $-4.9 \mathrm{ppm}$ and the doublets of doublets at -10.0 and $-10.1 \mathrm{ppm}$ in the ${ }^{1} \mathrm{H}$ decoupled spectrum did not change when the decoupler was turned off. The chemical shifts of the middle phosphorus atom $\left(\mathrm{P}_{\beta}\right)$ and the end phosphorus atom $\left(\mathrm{P}_{\gamma}\right)$ of monoimidotriphosphate derivatives usually appear at -10.0 and $-6.0 \mathrm{ppm}$, respectively. ${ }^{20-}$ 22) Therefore, the doublets at -4.8 and $-4.9 \mathrm{ppm}$ and the doublets of doublets at -10.0 and $-10.1 \mathrm{ppm}$ were assigned to $\mathrm{P}_{\gamma}$ and $\mathrm{P}_{\beta}$, respectively. Compared with the triphosphate ester of D-glucose, the chemical shifts of $\mathrm{P}_{\alpha}$ and $\mathrm{P}_{\beta}$ of $\mathbf{5}$ and 6 were shifted downfield, whereas there was no shift for $\mathrm{P}_{\gamma}$. Also, the values of $J_{\mathrm{P}_{\alpha}, \mathrm{P}_{\beta}}$ of $\mathbf{5}$ and $\mathbf{6}$ were one-third of $J_{\mathrm{P}_{\alpha}, \mathrm{P}_{\beta}}$ for the triphosphate ester of D-glucose, ${ }^{13)}$ and the values of $J_{\mathrm{P}_{\beta}, \mathrm{P}}$ of 5 and $\mathbf{6}$ were the same as that of the triphosphate ester of D-glucose. ${ }^{13)}$ These results suggest the existence of an $-\mathrm{O}-\mathrm{P}_{\alpha}-\mathrm{NH}-\mathrm{P}_{\beta}-$ bond in the phosphorylated products 5 and 6. Therefore, $\mathbf{5}$ and $\mathbf{6}$ were confirmed to be diphosphorami-

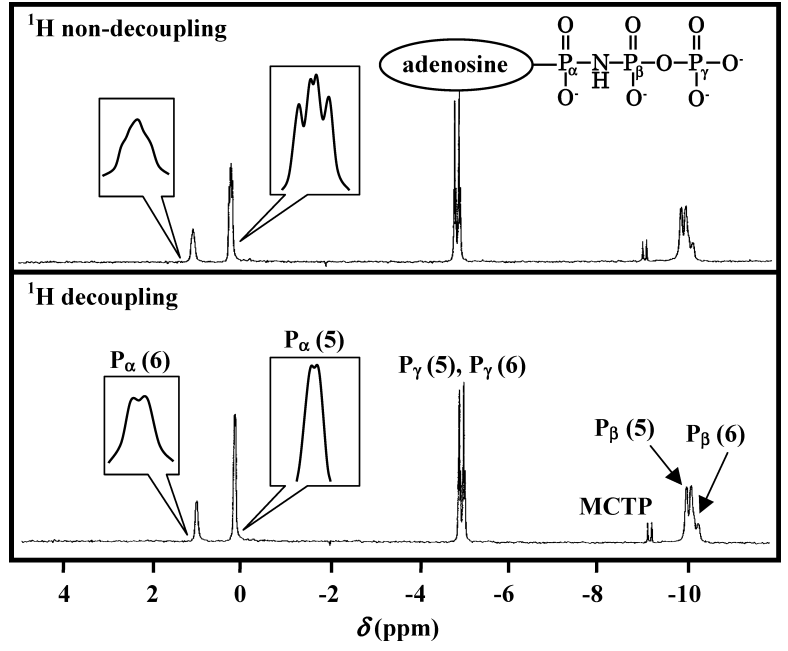

Fig. 4. ${ }^{31} \mathrm{P}-\mathrm{NMR}$ Spectra of 5 and $\mathbf{6}$

MCTP : adenosine $(\mathbf{1})=0.4 \mathrm{M}: 0.1 \mathrm{M}, \mathrm{pH} 12$, and $40^{\circ} \mathrm{C}$, after $22 \mathrm{~d}$.

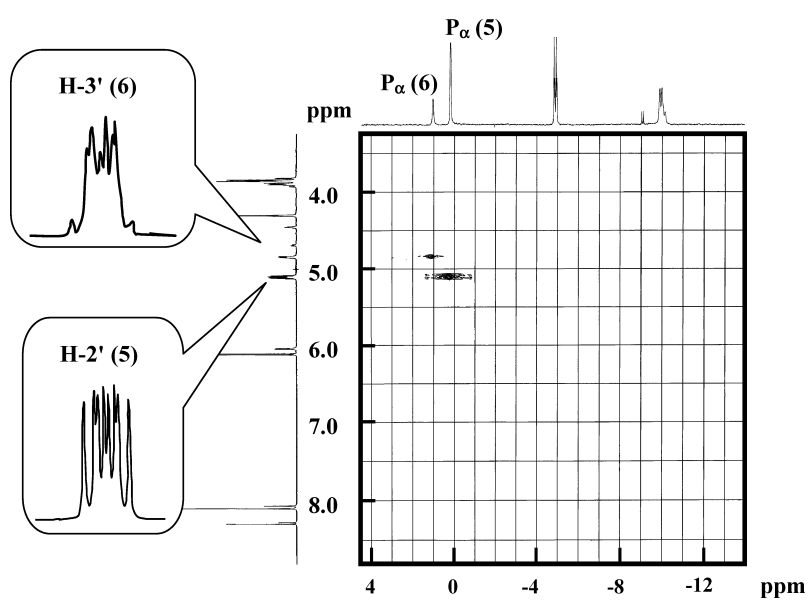

Fig. 5. ${ }^{1} \mathrm{H}-{ }^{31} \mathrm{P} 2 \mathrm{D}$ HMBC NMR Spectrum of 5 and $\mathbf{6}$

MCTP : adenosine $(\mathbf{1})=0.4 \mathrm{M}: 0.1 \mathrm{M}, \mathrm{pH} 12$, and $40^{\circ} \mathrm{C}$, after $22 \mathrm{~d}$.

\section{dophosphonoadenosines.}

Figure 5 shows the ${ }^{1} \mathrm{H}-{ }^{31} \mathrm{P}$ heteronuclear multiple bond correlation (HMBC) NMR spectrum of 5 and $\mathbf{6}$. The ${ }^{1} \mathrm{H}-{ }^{31} \mathrm{P}$ 2D HMBC NMR experiment showed a correlation between $\mathrm{P}_{\alpha}$ at $0.3 \mathrm{ppm}$ and the ${ }^{1} \mathrm{H}$ signal at $5.10 \mathrm{ppm}$. The signal at $5.10 \mathrm{ppm}$ was assigned to $\mathrm{H}-2^{\prime}$ of 5 based on the ${ }^{1} \mathrm{H}-{ }^{1} \mathrm{H}$ COSY spectrum. The ${ }^{3} J_{\mathrm{P}_{\alpha, \mathrm{H}-2^{\prime}}}$ value $(8.8 \mathrm{~Hz})$ from the ${ }^{1} \mathrm{H}-$ NMR spectrum is consistent with that deduced from ${ }^{31} \mathrm{P}$ NMR data. From these results, 5 was confirmed to be $2^{\prime}$ diphosphoramidophosphonoadenosine.

Figure 5 also shows the correlation between $\mathrm{P}_{\alpha}$ at $1.1 \mathrm{ppm}$ (due to 6) and the ${ }^{1} \mathrm{H}$ signal at $4.78 \mathrm{ppm}$. The signal at $4.78 \mathrm{ppm}$ was assigned to $\mathrm{H}-3^{\prime}$ of 6 by the ${ }^{1} \mathrm{H}-{ }^{1} \mathrm{H}$ COSY experiment. ${ }^{13)}$ Product 6 was determined to be $3^{\prime}$-diphosphoramidophosphonoadenosine (6). This shows that 1 reacts with MCTP to form both 2'-diphosphoramidophosphonoadenosine (5) and $3^{\prime}$-diphosphoramidophosphonoadenosine (6). The main product was found to be $2^{\prime}$-diphosphoramidophosphonoadenosine (5) from the comparison of the intensities of the $\mathrm{P}_{\alpha}$ signals $(0.3,1.1 \mathrm{ppm})$ in the ${ }^{1} \mathrm{H}$ non-decoupled ${ }^{31} \mathrm{P}-\mathrm{NMR}$ spectrum.

Table 1 summarizes the total yield of $\mathbf{5}$ and $\mathbf{6}$ obtained from the reaction of $\mathbf{1}$ with MCTP under various conditions. 
Table 1. Total Yields of Phosphoylated Products, 5 and $\mathbf{6}$ at Various Reaction Condition

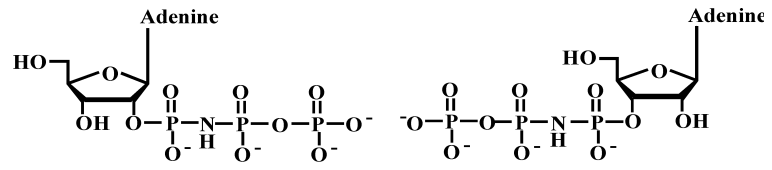

5

\begin{tabular}{lccccc}
\hline \hline \multicolumn{1}{c}{ Conc. $(\mathrm{mol} / \mathrm{l})$} & $\begin{array}{c}\text { Temp. } \\
\left({ }^{\circ} \mathrm{C}\right)\end{array}$ & $\mathrm{pH}$ & $\begin{array}{c}\text { Time } \\
(\mathrm{d})\end{array}$ & $\begin{array}{c}\text { Yield } \\
(\%)\end{array}$ \\
\cline { 1 - 4 } MCTP & & & & \\
\hline \multirow{2}{*}{0.4} & 0.2 & 40 & 12 & 15 & 42 \\
0.4 & 0.1 & 25 & 12 & 77 & 50 \\
& & 40 & 12 & 18 & 57 \\
& & 70 & 12 & 4 & 36 \\
& & 40 & 11 & 67 & 56 \\
0.4 & 40 & 13 & 9 & 33 \\
& 0.04 & 40 & 12 & 15 & 60 \\
\hline
\end{tabular}

Considering the yield and reaction time, the appropriate condition for phosphorylation of 1 with MCTP are $\mathrm{pH} 12,40^{\circ} \mathrm{C}$, and a molar ratio of MCTP : $\mathbf{1}=10(0.4 \mathrm{M}): 1(0.04 \mathrm{M})$. The total yield of 5 and $\mathbf{6}$ remained constant after $50 \mathrm{~d}$ without hydrolysis of the imidotriphosphate ester. This is in contrast to the reaction of 1 with $\mathrm{P}_{3 \mathrm{~m}}$. The products of the reaction of 1 with $\mathrm{P}_{3 \mathrm{~m}}$ are $2^{\prime}$-monophosphate, $3^{\prime}$-monophosphate, and $2^{\prime}, 3^{\prime}$-cyclicmonophosphate. The triphosphate derivatives of $\mathbf{1}$ are also produced as intermediates and decomposed to monophosphate derivatives immediately. It was concluded that the stability of the phosphorylated nucleoside was improved by use of MCTP.

The reactions of guanosine (2), cytidine (3) and uridine (4) with MCTP were also carried out under the same reaction conditions as $\mathbf{1}$. In HPLC profile of the reaction solution of 2-4 with MCTP, a single peak due to each phosphorylated product was obtained. However, each ${ }^{31} \mathrm{P}-\mathrm{NMR}$ spectrum showed two imidotriphosphate esters, $\mathbf{7}$ and $\mathbf{8}$ for $\mathbf{2 , 9}$ and $\mathbf{1 0}$ for 3, and $\mathbf{1 1}$ and $\mathbf{1 2}$ for $\mathbf{4}$, respectively. The yields of the products at $\mathrm{pH} 12,40^{\circ} \mathrm{C}$, and a molar ratio of MCTP : $\mathbf{2}$ $4=10(0.4 \mathrm{M}): 1(0.04 \mathrm{M})$ increased with reaction time and the total yield of 7 and $\mathbf{8}$ reached $45 \%$ (after $22 \mathrm{~d}$ ), that of $\mathbf{9}$ and 10 reached 34\% (after $21 \mathrm{~d}$ ), and that of $\mathbf{1 1}$ and $\mathbf{1 2}$ reached $30 \%$ (after $21 \mathrm{~d}$ ). The yields of $\mathbf{5}-\mathbf{8}$ are higher than that of 9-12 due to the effect of the base. Therefore, 2-4 react with MCTP to form 2 '-diphosphoramidophosphononucleoside $(7,9,11)$ and $3^{\prime}$-diphosphoramidophosphononucleoside $(\mathbf{8}, \mathbf{1 0}, 12)$ by ${ }^{1} \mathrm{H}-{ }^{1} \mathrm{H}$ COSY and ${ }^{1} \mathrm{H}-{ }^{1} \mathrm{H}$ total correlation spectroscopy (TOCSY) NMR experiments.

Phosphorylation of Adenosine 5'-Monophosphate (13), Guanosine 5'-Monophosphate (14), Cytidine 5'-Monophosphate (15) and Uridine $5^{\prime}$-Monophosphate (16) with MCTP Figure 6 shows the changes of the amounts of reaction products in the reaction of adenosine $5^{\prime}$-monophosphate (13) $(0.1 \mathrm{M})$ with $\mathrm{MCTP}(0.4 \mathrm{M})$ at $\mathrm{pH} 12$ and $40^{\circ} \mathrm{C}$. The HPLC profile of the reaction of 13 with MCTP showed two peaks attributable to the reaction products 17 and 18 although they could not be separated completely. The total amounts of $\mathbf{1 7}$ and $\mathbf{1 8}$ increased with reaction time to reach $22 \%$ after $21 \mathrm{~d}$ and constant after $50 \mathrm{~d}$ without hydrolysis of the imidotriphosphate ester.

In the reactions of $\mathbf{1 4}, \mathbf{1 5}$, and 16 with MCTP, two phos-

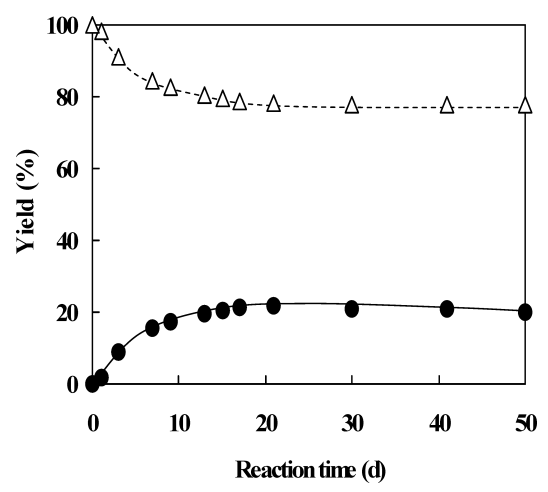

Fig. 6. Changes of the Amounts of Reaction Products in the Reaction of Adenosine $5^{\prime}$-Monophosphate $(0.1 \mathrm{M})$ with $\mathrm{MCTP}(0.4 \mathrm{M})$ at $\mathrm{pH} 12$ and $40{ }^{\circ} \mathrm{C}$

: 17 and 18, $\triangle$ : adenosine $5^{\prime}$-monophosphate.

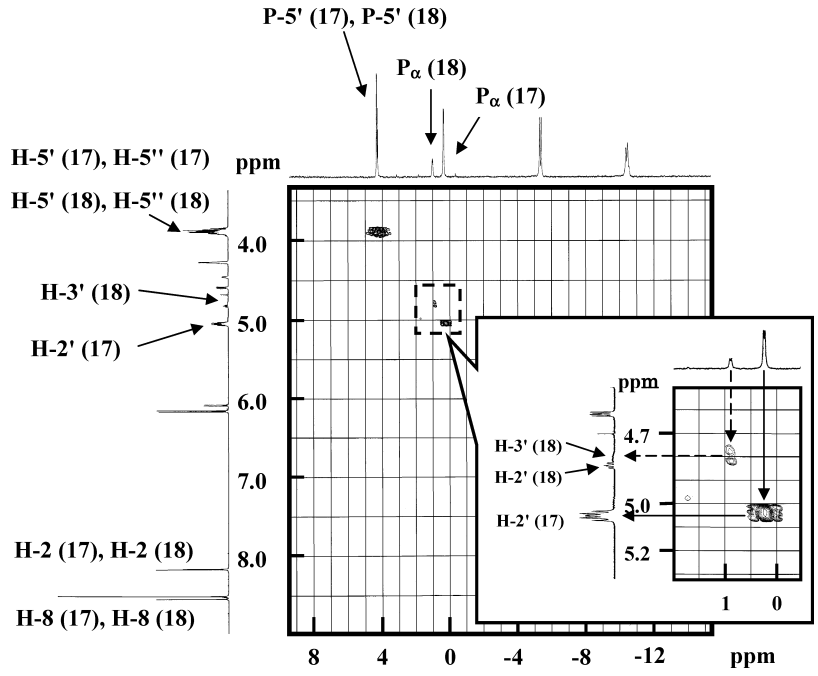

Fig. 7. ${ }^{1} \mathrm{H}^{-31} \mathrm{P}$ 2D HMBC NMR Spectrum of $\mathbf{1 7}$ and $\mathbf{1 8}$

MCTP : adenosine $5^{\prime}$-monophosphate $(\mathbf{1 3})=0.4 \mathrm{~m}: 0.1 \mathrm{M}, \mathrm{pH} 12$, and $40^{\circ} \mathrm{C}$, after $18 \mathrm{~d}$

phorylated products were also observed in the ${ }^{31} \mathrm{P}-\mathrm{NMR}$ spectra. The maximum yield of 19 and 20 for 14, that of 21 and $\mathbf{2 2}$ for $\mathbf{1 5}$, and that of $\mathbf{2 3}$ and $\mathbf{2 4}$ for 16, were 21, 19 and $14 \%$, respectively. Compared with the yields of 5-12, the yields of 17-24 were lower. This is due to electrostatic repulsion between the MCTP and the monophosphate group at the $5^{\prime}$ position.

To identify $\mathbf{1 7 - 2 4},{ }^{31} \mathrm{P}$ - and ${ }^{1} \mathrm{H}-\mathrm{NMR}$ spectra were measured. Figure 7 shows a representative ${ }^{1} \mathrm{H}-{ }^{31} \mathrm{P} 2 \mathrm{D}$ HMBC correlation spectrum of 17 and 18. In the ${ }^{31} \mathrm{P}-\mathrm{NMR}$ spectrum, the peak at $0.3 \mathrm{ppm}$ was assigned to $\mathrm{P}_{\alpha}$ of 17 , and the peak at $0.9 \mathrm{ppm}$ to $\mathrm{P}_{\alpha}$ of 18. The doublet at $-5.3 \mathrm{ppm}$ and the doublet of doublets at $-10.5 \mathrm{ppm}$ were assigned to $\mathrm{P}_{\gamma}$ and $\mathrm{P}_{\beta}$, respectively. The spectrum showed a correlation between $\mathrm{P}_{\alpha}$ at $0.3 \mathrm{ppm}$ and the ${ }^{1} \mathrm{H}$ signal at $5.04 \mathrm{ppm}$. The signal at $5.04 \mathrm{ppm}$ was assigned to $\mathrm{H}-2^{\prime}$ of $\mathbf{1 7}$ based on the ${ }^{1} \mathrm{H}-{ }^{1} \mathrm{H}$ COSY spectrum. The downfield shift from $4.62 \mathrm{ppm}\left(\mathrm{H}-2^{\prime}\right.$ of 17) to $5.04 \mathrm{ppm}$ is the result of phosphorylation. The other ${ }^{1} \mathrm{H}-\mathrm{NMR}$ signals of 17 were assigned by ${ }^{1} \mathrm{H}-{ }^{1} \mathrm{H}$ COSY and ${ }^{1} \mathrm{H}-{ }^{1} \mathrm{H}$ TOCSY NMR experiments. In this way, the main product 17 was confirmed to be $2^{\prime}$-diphosphoramidophosphonoadenosine $5^{\prime}$-monophosphate (17). 
Figure 7 also shows a correlation between $\mathrm{P}_{\alpha}$ at $0.9 \mathrm{ppm}$ (due to 18) and the $\mathrm{H}-3^{\prime}$ at $4.78 \mathrm{ppm}$. The signal at $4.78 \mathrm{ppm}$ was assigned to $\mathrm{H}-3^{\prime}$ of 18 by a ${ }^{1} \mathrm{H}-{ }^{1} \mathrm{H}$ COSY experiments. Therefore, product 18 was determined to be $3^{\prime}$ diphosphoramidophosphonoadenosine $\quad 5^{\prime}$-monophosphate. In the reaction of 14-16 with MCTP, the phosphorylated products 19-24 were verified to be $2^{\prime}$-diphosphoramidophosphonoguanosine 5'-monophosphate (19), 3'-diphosphoramidophosphonoguanosine $5^{\prime}$-monophosphate (20), 2'diphosphoramidophosphonocytidine $5^{\prime}$-monophosphate (21), $3^{\prime}$-diphosphoramidophosphonocytidine $\quad 5^{\prime}$-monophosphate (22), 2'-diphosphoramidophosphonouridine 5'-monophosphate (23), and $3^{\prime}$-diphosphoramidophosphonouridine $5^{\prime}$ monophosphate (24), respectively, from the results of ${ }^{31} \mathrm{P}$-, ${ }^{1} \mathrm{H}-,{ }^{1} \mathrm{H}-{ }^{31} \mathrm{P}$ 2D HMBC, ${ }^{1} \mathrm{H}-{ }^{1} \mathrm{H}$ COSY and ${ }^{1} \mathrm{H}-{ }^{1} \mathrm{H}$ TOCSY NMR experiments. As mentioned above, 13-16 were phosphorylated by MCTP at the $2^{\prime}-\mathrm{OH}$ and $3^{\prime}-\mathrm{OH}$ positions of the $\beta$-D-ribofuranosyl unit similar to $\mathbf{1}-\mathbf{4}$.

Reaction Mechanism of Nucleosides and Nucleotides with MCTP The reaction of nucleosides (1-4) or nucleotides (13-16) with MCTP may be explained by the following mechanism (Chart 1). At $\mathrm{pH} \mathrm{12,} \mathrm{MCTP} \mathrm{is} \mathrm{easily} \mathrm{at-}$ tacked by nucleophilic reagents such as amines, ${ }^{20)}$ amino acids $^{21)}$ and D-glucose derivatives. ${ }^{22)}$ In the present study, the lone electron pair on the hydroxyl group of the $\beta$-D-ribofuranose unit nucleophilicly attacks a phosphorus atom of MCTP, cleaving its six-membered ring. It is noteworthy that the existence of hydrogen bonding between the $2^{\prime}-\mathrm{OH}$ or $3^{\prime}-\mathrm{OH}$ of $\beta$-D-ribofuranose and the oxygen atom of MCTP would make attack of MCTP easier. Therefore, nucleosides (1-4) or nucleotides $\left(\mathbf{1 3}\right.$-16) react with MCTP to form $2^{\prime}$-diphosphoramidophosphononucleosides $(\mathbf{7}, \mathbf{9}, \mathbf{1 1})$ and $3^{\prime}$-diphosphoramidophosphononucleosides $(\mathbf{8}, \mathbf{1 0}, \mathbf{1 2})$.

The reaction of nucleosides $(\mathbf{1}-\mathbf{4})$ or nucleotides $(\mathbf{1 3}$ 16) with $P_{3 m}$ gave triphosphate derivatives of nucleosides and nucleotides. ${ }^{10)}$ The triphosphate derivatives is immediately hydrolyzed to give nucleoside $2^{\prime}$-monophosphate and nucleoside $3^{\prime}$-monophosphate or nucleoside $2^{\prime}, 5^{\prime}$-diphosphate and nucleoside $3^{\prime}, 5^{\prime}$-diphosphate via a $2^{\prime}, 3^{\prime}$-cyclicmonophosphate derivative. Although the $\mathrm{P}-\mathrm{O}-\mathrm{P}$ linkages of the tri-

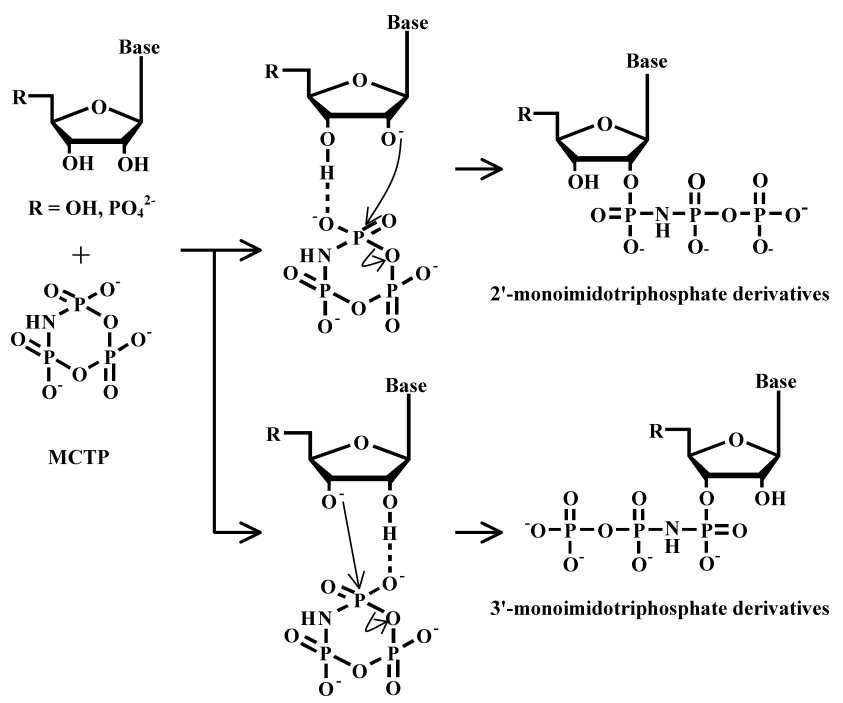

Chart 1. Phosphorylation Mechanism of Nucleosides and Nucleotides with MCTP phosphate derivatives of nucleosides and nucleotides were hydrolyzed to give monophosphate derivatives, the $\mathrm{P}-\mathrm{N}-\mathrm{P}$ linkages of monoimidotriphosphate derivatives are stable and difficult to hydrolyze.

Conclusion In the reactions of adenosine (1), guanosine (2), cytidine (3), and uridine (4) with MCTP, 2' -diphosphoramidophosphononucleosides $(\mathbf{5}, \mathbf{7}, \mathbf{9}, \mathbf{1 1})$ and $3^{\prime}$-diphosphoramidophosphononucleosides $(\mathbf{6}, \mathbf{8}, \mathbf{1 0}, \mathbf{1 2})$ were synthesized in yields of more than $30 \%$. The reactions of nucleotides (13-16) with MCTP produced 2'-diphosphoramidophosphononucleoside $5^{\prime}$-monophosphates similar to $\mathbf{1 - 4}$. In the reactions of nucleosides and nucleotides with MCTP, the $2^{\prime}$ $\mathrm{OH}$ or $3^{\prime}-\mathrm{OH}$ of the $\beta$-D-ribofuranose unit was phosphorylated. These results suggest that the synthesis of nucleoside triphosphate derivatives by MCTP is a promising area for development.

\section{Experimental}

Materials and Methods Monoimido-cyclo-triphosphate, $\mathrm{Na}_{3} \mathrm{P}_{3} \mathrm{O}_{8} \mathrm{NH}$ (MCTP), was prepared according to a previous paper. ${ }^{24)}$ Adenosine (1), guanosine (2), cytidine (3) uridine (4), adenosine $5^{\prime}$-monophosphate (13), guanosine $5^{\prime}$-monophosphate (14), cytidine $5^{\prime}$-monophosphate (15), uridine 5 '-monophosphate (16), and sodium 2,2-dimethyl-2-silapentane-5-sulfonate (DSS) were purchased from Yamasa Shoyu Co., Ltd. (Tokyo, Japan) and Sigma (St. Louis, U.S.A.). Unless otherwise stated, guaranteed grade reagents from Wako Chemical Industries, Ltd. (Osaka, Japan), were used.

${ }^{1} \mathrm{H}-\mathrm{NMR}$ spectra were measured with Varian Gemini 300 spectrometer. Samples were dissolved in $\mathrm{D}_{2} \mathrm{O}(99.9 \%)$ with DSS as an external standard. ${ }^{31} \mathrm{P}$-NMR spectra with and without broad band ${ }^{1} \mathrm{H}$-decoupling and ${ }^{1} \mathrm{H}-{ }^{31} \mathrm{P}$ 2D HMBC spectra were obtained with a Varian INOVA-500 spectrometer. As an external standard, $85 \% \mathrm{H}_{3} \mathrm{PO}_{4}$ was used.

HPLC analysis was carried out with a JASCO HPLC-800 system (Tokyo, Japan). A column $(150 \times 6.0 \mathrm{~mm}$ i.d. $)$ packed with a polystyrene-based anion-exchanger (TSK gel, SAX, $5 \mu \mathrm{m}$, TOSOH, Tokyo, Japan), was used for the analysis of phosphate. The column temperature was maintained at $45^{\circ} \mathrm{C}$. An isocratic elution technique using $0.27-0.35 \mathrm{~m}$ potassium chloride solutions was employed. The flow rate of the eluent was $1.0 \mathrm{ml} \cdot \mathrm{min}^{-1}$. The UV absorbance of the effluent was monitored continuously at $260 \mathrm{~nm}$ for the adenosine and 5'-AMP systems, $258 \mathrm{~nm}$ for the guanosine and 5'-GMP systems, $271 \mathrm{~nm}$ for the cytidine and $5^{\prime}$-CMP systems, and $262 \mathrm{~nm}$ for the uridine and $5^{\prime}$-UMP systems.

Synthetic Procedure The reaction of adenosine (1) $(0.0214 \mathrm{~g}, 0.04 \mathrm{M})$ with MCTP $(0.2583 \mathrm{~g}, 0.4 \mathrm{M})$ were dissolved in $\mathrm{H}_{2} \mathrm{O}(4 \mathrm{ml})$, and then the solution was adjusted to $\mathrm{pH} 12$ and $40^{\circ} \mathrm{C}$. The $\mathrm{pH}$ of the mixed solution was adjusted by adding $6 \mathrm{~m}$ sodium hydroxide solution. The separation of 5 and 6 from the reaction mixture was accomplished by anion-exchange chromatography with a $2 \times 80 \mathrm{~cm}$ column filled with Dowex 1 -X2 resin $(100-200$ mesh, chloride form). Elution was carried out with $0.3 \mathrm{~m}$ potassium chloride aqueous solution, and each $50 \mathrm{ml}$ fraction was measured by HPLC. The solution fractionated was concentrated at $-113^{\circ} \mathrm{C}$ in vacuo (freeze-drying). An aliquot of the obtained product was dissolved in $\mathrm{D}_{2} \mathrm{O}$ for HPLC, ${ }^{1} \mathrm{H}$ - and ${ }^{31} \mathrm{P}-\mathrm{NMR}$ measurements. Similar procedures were used for the syntheses of 7-12 and 17-24.

$2^{\prime}$-Diphosphoramidophosphonoadenosine (5): ${ }^{1} \mathrm{H}-\mathrm{NMR}\left(\mathrm{D}_{2} \mathrm{O}\right) \quad \delta: 6.12$ $\left(1 \mathrm{H}, \mathrm{d}, J_{1^{\prime}, 2^{\prime}}=6.6 \mathrm{~Hz}, \mathrm{H}-1^{\prime}\right), 5.10\left(1 \mathrm{H}, \mathrm{ddd}, J_{1^{\prime}, 2^{\prime}}=6.6 \mathrm{~Hz}, J_{2^{\prime}, 3^{\prime}}=5.0 \mathrm{~Hz}\right.$ $\left.J_{\mathrm{P}_{\mathrm{o}} \mathrm{H}-2^{\prime}}=8.8 \mathrm{~Hz}, \mathrm{H}-2^{\prime}\right), 4.68\left(1 \mathrm{H}, \mathrm{dd}, J_{2^{\prime}, 3^{\prime}}=5.0 \mathrm{~Hz}, J_{3^{\prime}, 4^{\prime}}=2.5 \mathrm{~Hz}, \mathrm{H}-3^{\prime}\right)$, $4.30\left(1 \mathrm{H}\right.$, ddd, $\left.J_{3^{\prime} 4^{\prime}}=2.5 \mathrm{~Hz}, J_{4^{\prime} 5^{\prime}}=3.0 \mathrm{~Hz}, J_{4^{\prime}, 5^{\prime \prime}}=3.5 \mathrm{~Hz}, \mathrm{H}-4^{\prime}\right), 3.86(1 \mathrm{H}$, ddd, $\left.J_{4^{\prime}, 5^{\prime}}=3.0 \mathrm{~Hz}, J_{4^{\prime}, 5^{\prime \prime}}=3.5 \mathrm{~Hz}, J_{5^{\prime}, 5^{\prime \prime}}=13.0 \mathrm{~Hz}, \mathrm{H}-5^{\prime}\right), 3.82\left(1 \mathrm{H}\right.$, ddd, $J_{4^{\prime}, 5^{\prime}}=$ $\left.3.0 \mathrm{~Hz}, J_{4^{\prime}, 5^{\prime \prime}}=3.5 \mathrm{~Hz}, J_{5^{\prime} 5^{\prime \prime}}=13.0 \mathrm{~Hz}, \mathrm{H}-5^{\prime \prime}\right) .{ }^{31} \mathrm{P}-\mathrm{NMR}\left(\mathrm{D}_{2} \mathrm{O}\right) \delta: 0.3(1 \mathrm{P}, \mathrm{dd}$, $\left.J_{\mathrm{P}_{\alpha} \mathrm{P}_{\mathrm{B}}}=6.1 \mathrm{~Hz}, J_{\mathrm{P}_{\alpha} \mathrm{H}-2^{2}}=8.8 \mathrm{~Hz}, \mathrm{P}_{\alpha}\right),-10.0 \quad\left(1 \mathrm{P}, \mathrm{dd}, J_{\mathrm{P}_{\alpha} \mathrm{P}_{\beta}}=6.1 \mathrm{~Hz}, J_{\mathrm{P}_{\mu} \mathrm{P}_{\mathrm{P}}}=\right.$ $\left.20.2 \mathrm{~Hz}, \mathrm{P}_{\beta}\right),-4.8\left(1 \mathrm{P}, \mathrm{d}, J_{\mathrm{P}_{\beta}, \mathrm{P}_{\gamma}}=20.2 \mathrm{~Hz}, \mathrm{P}_{\gamma}\right)$.

3'-Diphosphoramidophosphonoadenosine (6): ${ }^{1} \mathrm{H}-\mathrm{NMR}\left(\mathrm{D}_{2} \mathrm{O}\right) \quad \delta: 6.07$ $\left(1 \mathrm{H}, \mathrm{d}, J_{1^{\prime}, 2^{\prime}}=5.0 \mathrm{~Hz}, \mathrm{H}-1^{\prime}\right), 4.78\left(1 \mathrm{H}, \mathrm{dd}, J_{1^{\prime}, 2^{\prime}}=5.0 \mathrm{~Hz}, J_{2^{\prime}, 3^{\prime}}=5.0 \mathrm{~Hz}, \mathrm{H}-2^{\prime}\right)$, $4.78\left(1 \mathrm{H}\right.$, ddd, $\left.J_{2^{\prime}, 3^{\prime}}=5.0 \mathrm{~Hz}, J_{3^{\prime}, 4^{\prime}}=3.0 \mathrm{~Hz}, J_{\mathrm{P}_{\alpha} \mathrm{H}-3^{\prime}}=8.5 \mathrm{~Hz}, \mathrm{H}-3^{\prime}\right), 4.45(1 \mathrm{H}$, ddd, $\left.J_{3^{\prime}, 4^{\prime}}=3.0 \mathrm{~Hz}, J_{4^{\prime}, 5^{\prime}}=3.0 \mathrm{~Hz}, J_{4^{\prime}, 5^{\prime \prime}}=3.0 \mathrm{~Hz}, \mathrm{H}-4^{\prime}\right), 3.92\left(1 \mathrm{H}, \mathrm{ddd}, J_{4^{\prime}, 5^{\prime}}=\right.$ $\left.3.0 \mathrm{~Hz}, J_{4^{\prime}, 5^{\prime \prime}}=3.0 \mathrm{~Hz}, J_{5^{\prime}, 5^{\prime \prime}}=13.0 \mathrm{~Hz}, \mathrm{H}-5^{\prime}\right), 3.88\left(1 \mathrm{H}, \mathrm{ddd}, J_{4^{\prime}, 5^{\prime}}=3.0 \mathrm{~Hz}\right.$, $\left.J_{4^{\prime}, 5^{\prime \prime}}=3.0 \mathrm{~Hz}, J_{5^{\prime}, 5^{\prime \prime}}=13.0 \mathrm{~Hz}, \mathrm{H}-5^{\prime \prime}\right) .{ }^{31} \mathrm{P}-\mathrm{NMR}\left(\mathrm{D}_{2} \mathrm{O}\right) \delta: 1.1\left(1 \mathrm{P}, \mathrm{d}, J_{\mathrm{P}_{\mathrm{m}} \mathrm{P}_{\beta}}=6.1\right.$ $\left.\mathrm{Hz}, J_{\mathrm{P}_{\alpha} \mathrm{H}-3^{\prime}}=8.5 \mathrm{~Hz}, \mathrm{P}_{\alpha}\right),-10.1\left(1 \mathrm{P}, \mathrm{dd}, J_{\mathrm{P}_{\alpha} \mathrm{P}_{\beta}}=6.1 \mathrm{~Hz}, J_{\mathrm{P}_{\beta} \mathrm{P}_{\gamma}}=20.0 \mathrm{~Hz}, \mathrm{P}_{\beta}\right)$, $-4.9\left(1 \mathrm{P}, \mathrm{d}, J_{\mathrm{P}_{\mathrm{P}} \mathrm{P}}=20.0 \mathrm{~Hz}, \mathrm{P}_{\gamma}\right)$.

$2^{\prime}$-Diphosphoramidophosphonoguanosine (7): ${ }^{1} \mathrm{H}-\mathrm{NMR}\left(\mathrm{D}_{2} \mathrm{O}\right) \quad \delta: 5.85$ 
$\left(1 \mathrm{H}, \mathrm{d}, J_{1^{\prime}, 2^{\prime}}=6.5 \mathrm{~Hz}, \mathrm{H}-1^{\prime}\right), 4.99\left(1 \mathrm{H}, \mathrm{ddd}, J_{1^{\prime}, 2^{\prime}}=6.5 \mathrm{~Hz}, J_{2^{\prime}, 3^{\prime}}=5.5 \mathrm{~Hz}\right.$, $\left.J_{\mathrm{P}_{\omega} \mathrm{H}-2^{\prime}}=9.1 \mathrm{~Hz}, \mathrm{H}-2^{\prime}\right), 4.56\left(1 \mathrm{H}, \mathrm{dd}, J_{2^{\prime}, 3^{\prime}}=5.5 \mathrm{~Hz}, J_{3^{\prime}, 4^{\prime}}=4.5 \mathrm{~Hz}, \mathrm{H}-3^{\prime}\right)$, $4.14\left(1 \mathrm{H}\right.$, ddd, $\left.J_{3^{\prime}, 4^{\prime}}=4.5 \mathrm{~Hz}, J_{4^{\prime}, 5^{\prime}}=3.5 \mathrm{~Hz}, J_{4^{\prime}, 5^{\prime \prime}}=3.5 \mathrm{~Hz}, \mathrm{H}-4^{\prime}\right), 3.70(1 \mathrm{H}$, ddd, $\left.J_{4^{\prime} 5^{\prime}}=3.5 \mathrm{~Hz}, J_{4^{\prime} 5^{\prime \prime}}=3.5 \mathrm{~Hz}, J_{5^{\prime} 5^{\prime \prime}}=13.0 \mathrm{~Hz}, \mathrm{H}-5^{\prime}\right), 3.65(1 \mathrm{H}, \mathrm{ddd}$, $\left.J_{4^{\prime}, 5^{\prime}}=3.5 \mathrm{~Hz}, J_{4^{\prime}, 5^{\prime \prime}}=3.5 \mathrm{~Hz}, J_{5^{\prime}, 5^{\prime \prime}}=13.0 \mathrm{~Hz}, \mathrm{H}-5^{\prime \prime}\right) .{ }^{31} \mathrm{P}-\mathrm{NMR}\left(\mathrm{D}_{2} \mathrm{O}\right) \delta: 0.3$ $\left(1 \mathrm{P}, \mathrm{dd}, J_{\mathrm{P}_{\alpha} \mathrm{P}_{\beta}}=6.7 \mathrm{~Hz}, J_{\mathrm{P}_{\alpha} \mathrm{H}-2^{\prime}}=9.1 \mathrm{~Hz}, \mathrm{P}_{\alpha}\right),-10.0\left(1 \mathrm{P}, \mathrm{dd}, J_{\mathrm{P}_{\alpha} \mathrm{P}_{\beta}}=6.7 \mathrm{~Hz}\right.$, $\left.J_{\mathrm{P}_{\beta}, \mathrm{P}_{\mathrm{P}}}=20.6 \mathrm{~Hz}, \mathrm{P}_{\beta}\right),-4.7\left(1 \mathrm{P}, \mathrm{d}, J_{\mathrm{P}_{\beta}, \mathrm{P}_{\gamma}}=20.6 \mathrm{~Hz}, \mathrm{P}_{\gamma}\right)$.

3'-Diphosphoramidophosphonoguanosine (8): ${ }^{1} \mathrm{H}-\mathrm{NMR}\left(\mathrm{D}_{2} \mathrm{O}\right) \quad \delta: 5.79$ $\left(1 \mathrm{H}, \mathrm{d}, J_{1^{\prime}, 2^{\prime}}=6.0 \mathrm{~Hz}, \mathrm{H}-1^{\prime}\right), 4.75\left(1 \mathrm{H}, \mathrm{dd}, J_{1^{\prime}, 2^{\prime}}=6.0 \mathrm{~Hz}, J_{2^{\prime}, 3^{\prime}}=5.5 \mathrm{~Hz}, \mathrm{H}-2^{\prime}\right)$, $4.82\left(1 \mathrm{H}\right.$, ddd, $\left.J_{2^{\prime}, 3^{\prime}}=5.5 \mathrm{~Hz}, J_{3^{\prime}, 4^{\prime}}=3.5 \mathrm{~Hz}, J_{\mathrm{P}_{s} \mathrm{H}-3^{\prime}}=9.7 \mathrm{~Hz}, \mathrm{H}-3^{\prime}\right), 4.32(1 \mathrm{H}$, ddd, $\left.J_{3^{\prime}, 4^{\prime}}=3.5 \mathrm{~Hz}, J_{4^{\prime}, 5^{\prime}}=3.5 \mathrm{~Hz}, J_{4^{\prime}, 5^{\prime \prime}}=3.5 \mathrm{~Hz}, \mathrm{H}-4^{\prime}\right), 3.75(1 \mathrm{H}$, ddd $\left.J_{4^{\prime} 5^{\prime}}=3.5 \mathrm{~Hz}, J_{4^{\prime} 5^{\prime \prime}}=3.5 \mathrm{~Hz}, J_{5^{\prime} 5^{\prime \prime}}=13.0 \mathrm{~Hz}, \mathrm{H}-5^{\prime}\right), 3.68\left(1 \mathrm{H}, \mathrm{ddd}, J_{4^{\prime} 5^{\prime}}=3.5\right.$ $\left.\mathrm{Hz}, J_{4^{\prime} 5^{\prime \prime}}=3.5 \mathrm{~Hz}, J_{5^{\prime} 5^{\prime \prime}}=13.0 \mathrm{~Hz}, \mathrm{H}-5^{\prime \prime}\right) .{ }^{31} \mathrm{P}-\mathrm{NMR}\left(\mathrm{D}_{2} \mathrm{O}\right) \delta: 0.9(1 \mathrm{P}, \mathrm{dd}$ $\left.J_{\mathrm{P}_{\alpha} \mathrm{P}_{\beta}}=6.7 \mathrm{~Hz}, J_{\mathrm{P}_{\alpha} \mathrm{H}-3^{\prime}}=9.7 \mathrm{~Hz}, \mathrm{P}_{\alpha}\right),-10.1\left(1 \mathrm{P}, \mathrm{dd}, J_{\mathrm{P}_{\alpha} \mathrm{P}_{\beta}}=6.7 \mathrm{~Hz}, J_{\mathrm{P}_{\beta} \mathrm{P}_{\gamma}}=20.2 \mathrm{~Hz}\right.$, $\left.\mathrm{P}_{\beta}\right),-4.8\left(1 \mathrm{P}, \mathrm{d}, J_{\mathrm{P}_{\mathrm{P}} \mathrm{P}}=20.2 \mathrm{~Hz}, \mathrm{P}_{\gamma}\right)$

$2^{\prime}$-Diphosphoramidophosphonocytidine (9): ${ }^{1} \mathrm{H}-\mathrm{NMR}\left(\mathrm{D}_{2} \mathrm{O}\right) \delta: 5.97(1 \mathrm{H}$, d, $\left.J_{1^{\prime} 2^{\prime}}=6.5 \mathrm{~Hz}, \mathrm{H}-1^{\prime}\right), 4.60\left(1 \mathrm{H}, \mathrm{ddd}, J_{1^{\prime} 2^{\prime}}=6.5 \mathrm{~Hz}, J_{2^{\prime} 3^{\prime}}=5.5 \mathrm{~Hz}, J_{\mathrm{P}-\mathrm{H}-2^{\prime}}=\right.$ $\left.9.5 \mathrm{~Hz}, \mathrm{H}-2^{\prime}\right), 4.41\left(1 \mathrm{H}, \mathrm{dd}, J_{2^{\prime}, 3^{\prime}}=5.5 \mathrm{~Hz}, J_{3^{\prime}, 4^{\prime}}=3.5 \mathrm{~Hz}, \mathrm{H}-3^{\prime}\right), 4.01(1 \mathrm{H}$, ddd, $\left.J_{3^{\prime}, 4^{\prime}}=3.5 \mathrm{~Hz}, J_{4^{\prime}, 5^{\prime}}=3.5 \mathrm{~Hz}, J_{4^{\prime}, 5^{\prime \prime}}=3.5 \mathrm{~Hz}, \mathrm{H}-4^{\prime}\right), 3.67\left(1 \mathrm{H}\right.$, ddd, $J_{4^{\prime}, 5^{\prime}}=$ $\left.3.5 \mathrm{~Hz}, J_{4^{\prime}, 5^{\prime \prime}}=3.5 \mathrm{~Hz}, J_{5^{\prime}, 5^{\prime \prime}}=13.0 \mathrm{~Hz}, \mathrm{H}-5^{\prime}\right), 3.67\left(1 \mathrm{H}, \mathrm{ddd}, J_{4^{\prime}, 5^{\prime}}=3.5 \mathrm{~Hz}\right.$, $\left.J_{4^{\prime} 5^{\prime \prime}}=3.5 \mathrm{~Hz}, J_{5^{\prime}, 5^{\prime \prime}}=12.5 \mathrm{~Hz}, \mathrm{H}-5^{\prime \prime}\right) .{ }^{31} \mathrm{P}-\mathrm{NMR}\left(\mathrm{D}_{2} \mathrm{O}\right) \delta: 0.3\left(1 \mathrm{P}, \mathrm{dd}, J_{\mathrm{P} \mathrm{P}}=\right.$ $\left.6.2 \mathrm{~Hz}, J_{\mathrm{P}_{\alpha} \mathrm{H}-2^{\prime}}=9.5 \mathrm{~Hz}, \mathrm{P}_{\alpha}\right),-10.3\left(1 \mathrm{P}, \mathrm{dd}, J_{\mathrm{P}_{\alpha} \mathrm{P}_{\beta}}=6.2 \mathrm{~Hz}, J_{\mathrm{P}_{\beta} \mathrm{P}_{\gamma}}=20.8 \mathrm{~Hz}, \mathrm{P}_{\beta}\right)$, $-5.0\left(1 \mathrm{P}, J_{\mathrm{P}_{\mathrm{P}} \mathrm{P}}=20.8 \mathrm{~Hz}, \mathrm{P}_{\gamma}\right)$.

3'-Diphosphoramidophosphonocytidine (10): ${ }^{1} \mathrm{H}-\mathrm{NMR}\left(\mathrm{D}_{2} \mathrm{O}\right) \quad \delta: 5.81$ $\left(1 \mathrm{H}, \mathrm{d}, J_{1^{\prime}, 2^{\prime}}=5.5 \mathrm{~Hz}, \mathrm{H}-1^{\prime}\right), 4.33\left(1 \mathrm{H}, \mathrm{dd}, J_{1^{\prime}, 2^{\prime}}=5.5 \mathrm{~Hz}, J_{2^{\prime}, 3^{\prime}}=5.5 \mathrm{~Hz}, \mathrm{H}-2^{\prime}\right)$, $4.51\left(1 \mathrm{H}, \mathrm{ddd}, J_{2^{\prime}, 3^{\prime}}=5.5 \mathrm{~Hz}, J_{3^{\prime}, 4^{\prime}}=2.5 \mathrm{~Hz}, J_{\mathrm{P}_{0} \mathrm{H}-2^{\prime}}=9.3 \mathrm{~Hz}, \mathrm{H}-3^{\prime}\right), 4.13(1 \mathrm{H}$, ddd, $\left.J_{3^{\prime} 4^{\prime}}=2.5 \mathrm{~Hz}, J_{4^{\prime}, 5^{\prime}}=2.5 \mathrm{~Hz}, J_{4^{\prime} 5^{\prime \prime}}=4.5 \mathrm{~Hz}, \mathrm{H}-4^{\prime}\right), 3.79\left(1 \mathrm{H}, \mathrm{ddd}, J_{4^{\prime} 5^{\prime}}=\right.$ $\left.2.5 \mathrm{~Hz}, J_{4^{\prime}, 5^{\prime \prime}}=4.5 \mathrm{~Hz}, J_{5^{\prime}, 5^{\prime \prime}}=12.5 \mathrm{~Hz}, \mathrm{H}-5^{\prime}\right), 3.74\left(1 \mathrm{H}, \mathrm{ddd}, J_{4^{\prime}, 5^{\prime}}=2.5 \mathrm{~Hz}\right.$, $\left.J_{4^{\prime} 5^{\prime \prime}}=4.5 \mathrm{~Hz}, J_{5^{\prime}, 5^{\prime \prime}}=12.5 \mathrm{~Hz}, \mathrm{H}-5^{\prime \prime}\right) .{ }^{31} \mathrm{P}-\mathrm{NMR}\left(\mathrm{D}_{2} \mathrm{O}\right) \delta: 0.8\left(1 \mathrm{P}, \mathrm{dd}, J_{\mathrm{P}}{ }_{\mathrm{P}}=\right.$ $\left.6.5 \mathrm{~Hz}, J_{\mathrm{P}_{\alpha} \mathrm{H}-3^{\prime}}=9.3 \mathrm{~Hz}, \mathrm{P}_{\alpha}\right),-10.5\left(1 \mathrm{P}, \mathrm{dd}, J_{\mathrm{P}_{\alpha} \mathrm{P}_{\beta}}=6.5 \mathrm{~Hz}, J_{\mathrm{P}_{\beta} \mathrm{P}_{\gamma}}=21.0 \mathrm{~Hz}, \mathrm{P}_{\beta}\right)$, $-5.2\left(1 \mathrm{P}, \mathrm{d}, J_{\mathrm{P}, \mathrm{P}}=21.0 \mathrm{~Hz}, \mathrm{P}_{\gamma}\right)$.

$2^{\prime}$-Diphosphoramidophosphonouridine (11): ${ }^{1} \mathrm{H}-\mathrm{NMR}\left(\mathrm{D}_{2} \mathrm{O}\right) \delta: 5.98(1 \mathrm{H}$, d, $\left.J_{1^{\prime}, 2^{\prime}}=6.5 \mathrm{~Hz}, \mathrm{H}-1^{\prime}\right), 4.65\left(1 \mathrm{H}, \mathrm{ddd}, J_{1^{\prime}, 2^{\prime}}=6.5 \mathrm{~Hz}, J_{2^{\prime}, 3^{\prime}}=5.0 \mathrm{~Hz}, J_{\mathrm{P}_{\alpha} \mathrm{H}-2^{\prime}}=\right.$ $\left.8.5 \mathrm{~Hz}, \mathrm{H}-2^{\prime}\right), 4.45\left(1 \mathrm{H}, \mathrm{dd}, J_{2^{\prime}, 3^{\prime}}=5.0 \mathrm{~Hz}, J_{3^{\prime}, 4^{\prime}}=3.0 \mathrm{~Hz}, \mathrm{H}-3^{\prime}\right), 4.04(1 \mathrm{H}$, ddd, $\left.J_{3^{\prime}, 4^{\prime}}=3.0 \mathrm{~Hz}, J_{4^{\prime}, 5^{\prime}}=3.5 \mathrm{~Hz}, J_{4^{\prime}, 5^{\prime \prime}}=3.5 \mathrm{~Hz}, \mathrm{H}-4^{\prime}\right), 3.72\left(1 \mathrm{H}, \mathrm{ddd}, J_{4^{\prime}, 5^{\prime}}=\right.$ $\left.3.5 \mathrm{~Hz}, J_{4^{\prime}, 5^{\prime \prime}}=3.5 \mathrm{~Hz}, J_{5^{\prime}, 5^{\prime \prime}}=13.0 \mathrm{~Hz}, \mathrm{H}-5^{\prime}\right), 3.69\left(1 \mathrm{H}, \mathrm{ddd}, J_{4^{\prime}, 5^{\prime}}=3.5 \mathrm{~Hz}\right.$, $\left.J_{4^{\prime} 5^{\prime \prime}}=3.5 \mathrm{~Hz}, J_{5^{\prime} 5^{\prime \prime}}=13.0 \mathrm{~Hz}, \mathrm{H}-5^{\prime \prime}\right) .{ }^{31} \mathrm{P}-\mathrm{NMR}\left(\mathrm{D}_{2} \mathrm{O}\right) \delta: 0.1\left(1 \mathrm{P}, \mathrm{dd}, J_{\mathrm{P}}=\right.$ $\left.6.1 \mathrm{~Hz}, J_{\mathrm{P}_{\alpha} \mathrm{H}-2^{\prime}}=8.5 \mathrm{~Hz}, \mathrm{P}_{\alpha}\right),-10.8\left(1 \mathrm{P}, \mathrm{dd}, J_{\mathrm{P}_{\alpha} \mathrm{P}_{\beta}}=6.1 \mathrm{~Hz}, J_{\mathrm{P}_{\beta} \mathrm{P}_{\gamma}}=20.8 \mathrm{~Hz}, \mathrm{P}_{\beta}\right)$, $-5.4\left(1 \mathrm{P}, \mathrm{d}, J_{\mathrm{P} P}=20.8 \mathrm{~Hz}, \mathrm{P}_{\gamma}\right)$.

$3^{\prime}$-Diphosphoramidophosphonouridine (12): ${ }^{1} \mathrm{H}-\mathrm{NMR}\left(\mathrm{D}_{2} \mathrm{O}\right) \delta: 5.84(1 \mathrm{H}$, d, $\left.J_{1^{\prime}, 2^{\prime}}=5.0 \mathrm{~Hz}, \mathrm{H}-1^{\prime}\right), 4.38\left(1 \mathrm{H}, \mathrm{dd}, J_{1^{\prime}, 2^{\prime}}=5.0 \mathrm{~Hz}, J_{2^{\prime}, 3^{\prime}}=5.0 \mathrm{~Hz}, \mathrm{H}-2^{\prime}\right), 4.58$ $\left(1 \mathrm{H}\right.$, ddd, $\left.J_{2^{\prime}, 3^{\prime}}=5.0 \mathrm{~Hz}, J_{3^{\prime}, 4^{\prime}}=3.5 \mathrm{~Hz}, J_{\mathrm{P}_{\mathrm{c}} \mathrm{H}-3^{\prime}}=10.0 \mathrm{~Hz}, \mathrm{H}-3^{\prime}\right), 4.16(1 \mathrm{H}, \mathrm{ddd}$, $\left.J_{3^{\prime}, 4^{\prime}}=3.5 \mathrm{~Hz}, J_{4^{\prime}, 5^{\prime}}=3.0 \mathrm{~Hz}, J_{4^{\prime}, 5^{\prime \prime}}=3.0 \mathrm{~Hz}, \mathrm{H}-4^{\prime}\right), 3.77\left(1 \mathrm{H}, \mathrm{ddd}, J_{4^{\prime}, 5^{\prime}}=3.0\right.$ $\left.\mathrm{Hz}, J_{4^{\prime}, 5^{\prime \prime}}=3.0 \mathrm{~Hz}, J_{5^{\prime}, 5^{\prime \prime}}=13.0 \mathrm{~Hz}, \mathrm{H}-5^{\prime}\right), 3.70\left(1 \mathrm{H}, \mathrm{ddd}, J_{4^{\prime}, 5^{\prime}}=3.0 \mathrm{~Hz}, J_{4^{\prime}, 5^{\prime \prime}}=\right.$ $\left.3.0 \mathrm{~Hz}, J_{5^{\prime}, 5^{\prime \prime}}=13.0 \mathrm{~Hz}, \mathrm{H}-5^{\prime \prime}\right) .{ }^{31} \mathrm{P}-\mathrm{NMR}\left(\mathrm{D}_{2} \mathrm{O}\right) \delta: 0.6\left(1 \mathrm{P}, \mathrm{dd}, J_{\mathrm{P}_{\mathrm{N}}}=6.3 \mathrm{~Hz}\right.$, $\left.J_{\mathrm{P}_{\alpha} \mathrm{H}-3^{\prime}}=10.0 \mathrm{~Hz}, \mathrm{P}_{\alpha}\right),-10.8\left(1 \mathrm{P}, \mathrm{dd}, J_{\mathrm{P}_{\alpha} \mathrm{P}_{\beta}}=6.3 \mathrm{~Hz}, J_{\mathrm{P}_{\beta}, \mathrm{P}_{\gamma}}=20.8 \mathrm{~Hz}, \stackrel{\mathrm{P}}{\beta}_{\beta}\right),-5.4$ $\left(1 \mathrm{P}, \mathrm{d}, J_{\mathrm{P}_{\beta}, \mathrm{P}}=20.8 \mathrm{~Hz}, \mathrm{P}_{\gamma}\right)$.

2'-Diphosphoramidophosphonoadenosine $5^{\prime}$-Monophosphate (17): ${ }^{1} \mathrm{H}-$ NMR $\left(\mathrm{D}_{2} \mathrm{O}\right) \delta: 6.14\left(1 \mathrm{H}, \mathrm{d}, J_{1^{\prime}, 2^{\prime}}=6.0 \mathrm{~Hz}, \mathrm{H}-1^{\prime}\right), 5.04\left(1 \mathrm{H}, \mathrm{ddd}, J_{1^{\prime}, 2^{\prime}}=6.0\right.$ $\left.\mathrm{Hz}, J_{2^{\prime}, 3^{\prime}}=5.5 \mathrm{~Hz}, J_{\mathrm{P}_{\mathrm{c}} \mathrm{H}-2^{\prime}}=9.0 \mathrm{~Hz}, \mathrm{H}-2^{\prime}\right), 4.58\left(1 \mathrm{H}, \mathrm{dd}, J_{2^{\prime}, 3^{\prime}}=5.5 \mathrm{~Hz}, J_{3^{\prime}, 4^{\prime}}=\right.$ $\left.3.0 \mathrm{~Hz}, \mathrm{H}-3^{\prime}\right), 4.27^{\prime}\left(1 \mathrm{H}, \mathrm{ddd}, J_{3^{\prime}, 4^{\prime}}=3.0 \mathrm{~Hz}, J_{4^{\prime}, 5^{\prime}}=1.5 \mathrm{~Hz}, J_{4^{\prime}, 5^{\prime \prime}}=4.5 \mathrm{~Hz}\right.$, $\left.\mathrm{H}-4^{\prime}\right), 3.89\left(1 \mathrm{H}, \mathrm{m}, J_{4^{\prime}, 5^{\prime}}=1.5 \mathrm{~Hz}, J_{4^{\prime}, 5^{\prime \prime}}=4.5 \mathrm{~Hz}, J_{5^{\prime}, 5^{\prime \prime}}=12.0 \mathrm{~Hz}, J_{\mathrm{P}-5^{\prime}, \mathrm{H}-5^{\prime}}=3.6\right.$ $\left.\mathrm{Hz}, \mathrm{H}-5^{\prime}\right), 3.85\left(1 \mathrm{H}, \mathrm{m}, J_{4^{\prime} 5^{\prime}}=1.5 \mathrm{~Hz}, J_{4^{\prime} 5^{\prime \prime}}=4.5 \mathrm{~Hz}, J_{5^{\prime} 5^{\prime \prime}}=12.0 \mathrm{~Hz}\right.$, $\left.J_{\mathrm{P}-5^{\prime}, \mathrm{H}-5^{\prime \prime}}=3.6 \mathrm{~Hz}, \quad \mathrm{H}-5^{\prime \prime}\right) . \quad{ }^{31} \mathrm{P}-\mathrm{NMR} \quad\left(\mathrm{D}_{2} \mathrm{O}\right) \quad \delta: \quad 0.3 \quad\left(1 \mathrm{P}, \quad \mathrm{dd}, \quad J_{\mathrm{P}_{\alpha} \mathrm{P}_{3}}=5.5\right.$ $\left.\mathrm{Hz}, \quad J_{\mathrm{P}_{\alpha} \mathrm{H}-2^{2}}=9.0 \mathrm{~Hz}, \mathrm{P}_{\alpha}\right),-10.6\left(1 \mathrm{P}, \quad \mathrm{dd}, J_{\mathrm{P}_{\alpha} \mathrm{P}_{\beta}}=5.5 \mathrm{~Hz}, J_{\mathrm{P}_{\beta}, \mathrm{P}_{\mathrm{\gamma}}}=20.6 \mathrm{~Hz}\right.$

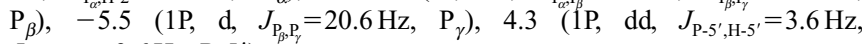
$\left.J_{\mathrm{P}-5^{\prime} \mathrm{H}-5^{\prime \prime}}=3.6 \mathrm{~Hz}, \mathrm{P}-5^{\prime}\right)$.

$3^{\prime}$-Diphosphoramidophosphonoadenosine $5^{\prime}$-Monophosphate (18): ${ }^{1} \mathrm{H}$ $\operatorname{NMR}\left(\mathrm{D}_{2} \mathrm{O}\right) \delta: 6.07\left(1 \mathrm{H}, \mathrm{d}, J_{1^{\prime}, 2^{\prime}}=6.0 \mathrm{~Hz}, \mathrm{H}-1^{\prime}\right), 4.81\left(1 \mathrm{H}, \mathrm{dd}, J_{1^{\prime}, 2^{\prime}}=6.5 \mathrm{~Hz}\right.$, $\left.J_{2^{\prime}, 3^{\prime}}=4.5 \mathrm{~Hz}, \mathrm{H}-2^{\prime}\right), 4.78\left(1 \mathrm{H}, \mathrm{ddd}, J_{2^{\prime}, 3^{\prime}}=4.5 \mathrm{~Hz}, J_{3^{\prime}, 4^{\prime}}=4.5 \mathrm{~Hz}, J_{\mathrm{P}_{\infty} \mathrm{H}-3^{\prime}}=\right.$ $\left.8.7 \mathrm{~Hz}, \mathrm{H}-3^{\prime}\right), 4.45\left(1 \mathrm{H}\right.$, ddd, $J_{3^{\prime}, 4^{\prime}}=4.5 \mathrm{~Hz}, J_{4^{\prime}, 5^{\prime}}=1.5 \mathrm{~Hz}, J_{4^{\prime}, 5^{\prime \prime}}=4.0 \mathrm{~Hz}$, $\left.\mathrm{H}-4^{\prime}\right), 3.92\left(1 \mathrm{H}, \mathrm{m}, J_{4^{\prime}, 5^{\prime}}=1.5 \mathrm{~Hz}, J_{4^{\prime}, 5^{\prime \prime}}=4.0 \mathrm{~Hz}, J_{5^{\prime}, 5^{\prime \prime}}=13.0 \mathrm{~Hz}, J_{\mathrm{P}-5^{\prime}, \mathrm{H}-5^{\prime}}=\right.$ $\left.3.4 \mathrm{~Hz}, \mathrm{H}-5^{\prime}\right), 3.88\left(1 \mathrm{H}, \mathrm{m}, J_{4^{\prime} 5^{\prime}}=1.5 \mathrm{~Hz}, J_{4^{\prime} 5^{\prime \prime}}=4.0 \mathrm{~Hz}, J_{5^{\prime} 5^{\prime \prime}}=13.0 \mathrm{~Hz}\right.$, $\left.J_{\mathrm{P}-5^{\prime}, \mathrm{H}-5^{\prime \prime}}=3.4 \mathrm{~Hz}, \mathrm{H}-5^{\prime \prime}\right) .{ }^{31} \mathrm{P}-\mathrm{NMR} \quad\left(\mathrm{D}_{2} \mathrm{O}\right) \delta: 1.3\left(1 \mathrm{P}, \mathrm{dd}, J_{\mathrm{P}_{\alpha} \mathrm{P}_{\beta}}=6.1 \mathrm{~Hz}\right.$, $\left.J_{\mathrm{P}_{\mathrm{s}-\mathrm{H}-3^{\prime}}}=8.7 \mathrm{~Hz}, \mathrm{P}_{\alpha}\right),-10.0\left(1 \mathrm{P}, \mathrm{dd}, J_{\mathrm{P}_{\mathrm{P}} \mathrm{P}}=6.1 \mathrm{~Hz}, J_{\mathrm{P}_{\mathrm{P}} \mathrm{P}}=19.4 \mathrm{~Hz}, \mathrm{P}_{\beta}\right),-5.3$ $\left(1 \mathrm{P}, \mathrm{d}, J_{\mathrm{P}_{\beta}, \mathrm{P}_{\gamma}}=19.4 \mathrm{~Hz}, \mathrm{P}\right), 4.2\left(1 \mathrm{P}, \mathrm{dd}, J_{\mathrm{P}-5^{\prime}, \mathrm{H}-5^{\prime}}=3.4 \mathrm{~Hz}, J_{\mathrm{P}-5^{\prime}, \mathrm{H}-5^{\prime \prime}}=3.4 \mathrm{~Hz}, \mathrm{P}-\right.$ $\left.5^{\prime}\right)$.

2'-Diphosphoramidophosphonoguanosine $5^{\prime}$-Monophosphate (19): ${ }^{1} \mathrm{H}-$ $\operatorname{NMR}\left(\mathrm{D}_{2} \mathrm{O}\right) \delta: 5.96\left(1 \mathrm{H}, \mathrm{d}, J_{1^{\prime}, 2^{\prime}}=5.5 \mathrm{~Hz}, \mathrm{H}-1^{\prime}\right), 4.98\left(1 \mathrm{H}, \mathrm{ddd}, J_{1^{\prime} 2^{\prime}}=5.5\right.$ $\left.\mathrm{Hz}, J_{2^{\prime}, 3^{\prime}}=5.5 \mathrm{~Hz}, J_{\mathrm{P}_{\mathrm{c}} \mathrm{H}-2^{\prime}}=9.7 \mathrm{~Hz}, \mathrm{H}-2^{\prime}\right), 4.53\left(1 \mathrm{H}, \mathrm{dd}, J_{2^{\prime}, 3^{\prime}}=5.5 \mathrm{~Hz}, J_{3^{\prime}, 4^{\prime}}=\right.$ $\left.5.0 \mathrm{~Hz}, \mathrm{H}-3^{\prime}\right), 4.21^{\prime \prime}\left(1 \mathrm{H}\right.$, ddd, $J_{3^{\prime} 4^{\prime}}=5.0 \mathrm{~Hz}, J_{4^{\prime}, 5^{\prime}}=4.0 \mathrm{~Hz}, J_{4^{\prime} 5^{\prime \prime}}=4.0 \mathrm{~Hz}$, $\left.\mathrm{H}-4^{\prime}\right), 3.91\left(1 \mathrm{H}, \mathrm{m}, J_{4^{\prime}, 5^{\prime}}=4.0 \mathrm{~Hz}, J_{4^{\prime}, 5^{\prime \prime}}=4.0 \mathrm{~Hz}, J_{5^{\prime}, 5^{\prime \prime}}=11.5 \mathrm{~Hz}, J_{\mathrm{P}-5^{\prime}, \mathrm{H}-5^{\prime}}=3.6\right.$ $\left.\mathrm{Hz}, \mathrm{H}-5^{\prime}\right), 3.84\left(1 \mathrm{H}, \mathrm{m}, J_{4^{\prime} 5^{\prime}}=4.0 \mathrm{~Hz}, J_{4^{\prime} 5^{\prime \prime}}=4.0 \mathrm{~Hz}, J_{5^{\prime} 5^{\prime \prime}}=11.5 \mathrm{~Hz}\right.$, $\left.J_{\mathrm{P}-5^{\prime}, \mathrm{H}-5^{\prime \prime}}=3.6 \mathrm{~Hz}, \quad \mathrm{H}-5^{\prime \prime}\right) . \quad{ }^{31} \mathrm{P}-\mathrm{NMR} \quad\left(\mathrm{D}_{2} \mathrm{O}\right) \quad \delta: \quad 0.5 \quad\left(1 \mathrm{P}, \quad \mathrm{dd}, \quad J_{\mathrm{P}_{\alpha} \mathrm{P}_{\beta}}=6.5\right.$
$\left.\mathrm{Hz}, \quad J_{\mathrm{P}_{\alpha} \mathrm{H}-2^{\prime}}=9.7 \mathrm{~Hz}, \quad \mathrm{P}_{\alpha}\right), \quad-9.8 \quad\left(1 \mathrm{P}, \quad \mathrm{dd}, \quad J_{\mathrm{P}_{\alpha} \mathrm{P}_{\beta}}=6.5 \mathrm{~Hz}, \quad J_{\mathrm{P}_{\beta} \mathrm{P}_{\mathrm{P}}}=19.6 \mathrm{~Hz}\right.$,

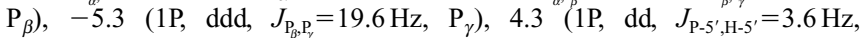
$\left.J_{\mathrm{P}-5^{\prime}, \mathrm{H}-5^{\prime \prime}}=3.6 \mathrm{~Hz}, \mathrm{P}-5^{\prime}\right)$.

3'-Diphosphoramidophosphonoguanosine $5^{\prime}$-Monophosphate (20): ${ }^{1} \mathrm{H}-$ $\operatorname{NMR}\left(\mathrm{D}_{2} \mathrm{O}\right) \delta: 5.85\left(1 \mathrm{H}, \mathrm{d}, J_{1^{\prime}, 2^{\prime}}=6.0 \mathrm{~Hz}, \mathrm{H}-1^{\prime}\right), 4.77\left(1 \mathrm{H}, \mathrm{dd}, J_{1^{\prime}, 2^{\prime}}=6.0 \mathrm{~Hz}\right.$, $\left.J_{2^{\prime}, 3^{\prime}}=5.0 \mathrm{~Hz}, \mathrm{H}-2^{\prime}\right), 4.75\left(1 \mathrm{H}, \mathrm{ddd}, J_{2^{\prime}, 3^{\prime}}=5.0 \mathrm{~Hz}, J_{3^{\prime}, 4^{\prime}}=3.0 \mathrm{~Hz}, J_{\mathrm{P}_{o} \mathrm{H}-3^{\prime}}=\right.$ $\left.8.7 \mathrm{~Hz}, \mathrm{H}-3^{\prime}\right), 4.39\left(1 \mathrm{H}\right.$, ddd, $J_{3^{\prime}, 4^{\prime}}=3.0 \mathrm{~Hz}, J_{4^{\prime}, 5^{\prime}}=3.0 \mathrm{~Hz}, J_{4^{\prime}, 5^{\prime \prime}}=3.0 \mathrm{~Hz}$, $\left.\mathrm{H}-4^{\prime}\right), 3.91\left(1 \mathrm{H}, \mathrm{m}, J_{4^{\prime}, 5^{\prime}}=3.0 \mathrm{~Hz}, J_{4^{\prime}, 5^{\prime \prime}}=3.0 \mathrm{~Hz}, J_{5^{\prime}, 5^{\prime \prime}}=11.5 \mathrm{~Hz}, J_{\mathrm{P}-5^{\prime}, \mathrm{H}-5^{\prime}}=\right.$ $\left.3.8 \mathrm{~Hz}, \mathrm{H}-5^{\prime}\right), 3.88\left(1 \mathrm{H}, \mathrm{m}, J_{4^{\prime}, 5^{\prime}}=3.0 \mathrm{~Hz}, J_{4^{\prime}, 5^{\prime \prime}}=3.0 \mathrm{~Hz}, J_{5^{\prime}, 5^{\prime \prime}}=11.5 \mathrm{~Hz}\right.$, $\left.J_{\mathrm{P}-5^{\prime}, \mathrm{H}-5^{\prime \prime}}=3.8 \mathrm{~Hz}, \mathrm{H}-5^{\prime \prime}\right) .{ }^{31} \mathrm{P}-\mathrm{NMR}\left(\mathrm{D}_{2} \mathrm{O}\right) \delta: 1.3\left(1 \mathrm{P}, \mathrm{dd}, J_{\mathrm{P}_{\alpha} \mathrm{P}_{\beta}}=6.1 \mathrm{~Hz}\right.$, $\left.J_{\mathrm{P}_{\alpha} \mathrm{H}-3^{\prime}}=8.7 \mathrm{~Hz}, \mathrm{P}_{\alpha}\right),-10.0\left(1 \mathrm{P}, \mathrm{dd}, J_{\mathrm{P}_{\alpha} \mathrm{P}_{\beta}}=6.1 \mathrm{~Hz}, J_{\mathrm{P}_{0} \mathrm{P}}=19.4 \mathrm{~Hz}, \mathrm{P}_{\beta}\right),-5.3$ $\left(1 \mathrm{P}, \mathrm{d}, J_{\mathrm{P}_{\beta}, \mathrm{P}_{\gamma}}=19.4 \mathrm{~Hz}, \mathrm{P}_{\gamma}\right), 4.2\left(1 \mathrm{P}, \mathrm{dd}, J_{\mathrm{P}-5^{\prime}, \mathrm{H}-5^{\prime}}=3.8 \mathrm{~Hz}, J_{\mathrm{P}-5^{\prime}, \mathrm{H}-5^{\prime \prime}}=3.8 \mathrm{~Hz}, \mathrm{P}-\right.$ $\left.5^{\prime}\right)$.

2'-Diphosphoramidophosphonocytidine $\quad 5^{\prime}$-Monophosphate (21): ${ }^{1} \mathrm{H}-$ $\operatorname{NMR}\left(\mathrm{D}_{2} \mathrm{O}\right) \delta: 6.32\left(1 \mathrm{H}, \mathrm{d}, J_{1^{\prime}, 2^{\prime}}=5.0 \mathrm{~Hz}, \mathrm{H}^{\prime} 1^{\prime}\right), 4.87\left(1 \mathrm{H}, \mathrm{ddd}, J_{1^{\prime}, 2^{\prime}}=5.0\right.$ $\left.\mathrm{Hz}, J_{2^{\prime}, 3^{\prime}}=5.5 \mathrm{~Hz}, J_{\mathrm{P}_{\infty} \mathrm{H}-2^{\prime}}=9.1 \mathrm{~Hz}, \mathrm{H}-2^{\prime}\right), 4.67\left(1 \mathrm{H}, \mathrm{dd}, J_{2^{\prime}, 3^{\prime}}=5.5 \mathrm{~Hz}, J_{3^{\prime}, 4^{\prime}}=\right.$ $\left.5.0 \mathrm{~Hz}, \mathrm{H}-3^{\prime}\right), 4.46\left(1 \mathrm{H}, \mathrm{ddd}, J_{3^{\prime}, 4^{\prime}}=5.0 \mathrm{~Hz}, J_{4^{\prime}, 5^{\prime}}=1.5 \mathrm{~Hz}, J_{4^{\prime}, 5^{\prime \prime}}=5.0 \mathrm{~Hz}\right.$, $\left.\mathrm{H}-4^{\prime}\right), 4.17\left(1 \mathrm{H}, \mathrm{m}, J_{4^{\prime}, 5^{\prime}}=1.5 \mathrm{~Hz}, J_{4^{\prime}, 5^{\prime \prime}}=5.0 \mathrm{~Hz}, J_{5^{\prime}, 5^{\prime \prime}}=11.5 \mathrm{~Hz}, J_{\mathrm{P}-5^{\prime}, \mathrm{H}-5^{\prime}}=\right.$ $\left.3.6 \mathrm{~Hz}, \mathrm{H}-5^{\prime}\right), 4.09\left(1 \mathrm{H}, \mathrm{m}, J_{4^{\prime}, 5^{\prime}}=1.5 \mathrm{~Hz}, J_{4^{\prime}, 5^{\prime \prime}}=5.0 \mathrm{~Hz}, J_{5^{\prime}, 5^{\prime \prime}}=11.5 \mathrm{~Hz}\right.$, $\left.J_{\mathrm{P}-5^{\prime}, \mathrm{H}-5^{\prime \prime}}=3.6 \mathrm{~Hz}, \mathrm{H}-5^{\prime \prime}\right) .{ }^{31} \mathrm{P}-\mathrm{NMR}\left(\mathrm{D}_{2} \mathrm{O}\right) \delta: 0.7\left(1 \mathrm{P}, \mathrm{dd}, J_{\mathrm{P}_{\alpha} \mathrm{P}_{\beta}}=6.7 \mathrm{~Hz}, J_{\mathrm{P}_{\alpha} \mathrm{H}-2^{\prime}}=\right.$ $\left.9.1 \mathrm{~Hz}, \mathrm{P}_{\alpha}\right),-9.4\left(1 \mathrm{P}, \mathrm{dd}, J_{\mathrm{P}_{\alpha} \mathrm{P}_{\beta}}=6.7 \mathrm{~Hz}, J_{\mathrm{P}_{\beta} \mathrm{P}}=19.6 \mathrm{~Hz}, \mathrm{P}_{\beta}\right),-4.2(1 \mathrm{P}, \mathrm{d}$, $\left.J_{\mathrm{P}_{\beta}, \mathrm{P}_{\mathrm{P}}}=19.6 \mathrm{~Hz}, \mathrm{P}_{\gamma}\right), 4.8\left(1 \mathrm{P}, \mathrm{dd}, J_{\mathrm{P}-5^{\prime}, \mathrm{H}-5^{\prime}}=3.6 \mathrm{~Hz}, J_{\mathrm{P}-5^{\prime}, \mathrm{H}-5^{\prime \prime}}=3.6 \mathrm{~Hz}, \mathrm{P}-5^{\prime}\right)$.

${ }_{3}^{\prime}$-Diphosphoramidophosphonocytidine $5^{\prime}$-Monophosphate (22): ${ }^{1} \mathrm{H}-$ $\operatorname{NMR}\left(\mathrm{D}_{2} \mathrm{O}\right) \delta: 6.17\left(1 \mathrm{H}, \mathrm{d}, J_{1^{\prime}, 2^{\prime}}=5.0 \mathrm{~Hz}, \mathrm{H}-1^{\prime}\right), 4.69\left(1 \mathrm{H}, \mathrm{dd}, J_{1^{\prime}, 2^{\prime}}=\right.$ $\left.5.0 \mathrm{~Hz}, J_{2^{\prime}, 3^{\prime}}=4.5 \mathrm{~Hz}, \mathrm{H}-2^{\prime}\right), 4.78^{\prime}\left(1 \mathrm{H}, \mathrm{ddd}, J_{2^{\prime}, 3^{\prime}}=4.5 \mathrm{~Hz}, J_{3^{\prime}, 4^{\prime}}=5.0 \mathrm{~Hz}\right.$, $\left.J_{\mathrm{P}_{o} \mathrm{H}-3^{\prime}}=8.5 \mathrm{~Hz}, \mathrm{H}-3^{\prime}\right), 4.59\left(1 \mathrm{H}, \mathrm{ddd}, J_{3^{\prime}, 4^{\prime}}=5.0 \mathrm{~Hz}, J_{4^{\prime}, 5^{\prime}}=2.5 \mathrm{~Hz}, J_{4^{\prime}, 5^{\prime \prime}}=\right.$ $\left.5.0 \mathrm{~Hz}, \mathrm{H}-4^{\prime}\right), 4.23\left(1 \mathrm{H}, \mathrm{m}, J_{4^{\prime}, 5^{\prime}}=2.5 \mathrm{~Hz}, J_{4^{\prime}, 5^{\prime \prime}}=5.0 \mathrm{~Hz}, J_{5^{\prime}, 5^{\prime \prime}}=11.5 \mathrm{~Hz}\right.$, $\left.J_{\mathrm{P}-5^{\prime}, \mathrm{H}-5^{\prime}}=3.4 \mathrm{~Hz}, \mathrm{H}-5^{\prime}\right), 4.10\left(1 \mathrm{H}, \mathrm{m}, J_{4^{\prime}, 5^{\prime}}=2.5 \mathrm{~Hz}, J_{4^{\prime}, 5^{\prime \prime}}=5.0 \mathrm{~Hz}, J_{5^{\prime}, 5^{\prime \prime}}=\right.$ $\left.11.5 \mathrm{~Hz}, J_{\mathrm{P}-5^{\prime}, \mathrm{H}-5^{\prime \prime}}=3.4 \mathrm{~Hz}, \mathrm{H}-5^{\prime \prime}\right) .{ }^{31} \mathrm{P}-\mathrm{NMR}\left(\mathrm{D}_{2} \mathrm{O}\right) \delta: 1.0\left(1 \mathrm{P}\right.$, dd, $J_{\mathrm{P}_{\infty} \mathrm{P}_{\beta}}=6.1$ $\left.\mathrm{Hz}, J_{\mathrm{P}_{\alpha} \mathrm{H}-3^{\prime}}=8.5 \mathrm{~Hz}, \mathrm{P}_{\alpha}\right),-9.5\left(1 \mathrm{P}, \mathrm{dd}, J_{\mathrm{P}_{\alpha} \mathrm{P}_{\beta}}=6.1 \mathrm{~Hz}, J_{\mathrm{P}_{\beta}, \mathrm{P}_{\gamma}}=20.2 \mathrm{~Hz}, \mathrm{P}_{\beta}\right)$, $-4.3\left(1 \mathrm{P}, \mathrm{d}, J_{\mathrm{P}_{\beta}, \mathrm{P}}=20.2 \mathrm{~Hz}, \mathrm{P}_{\gamma}\right), 4.8\left(1 \mathrm{P}, \stackrel{\mathrm{dd}}{{ }^{\prime}}, J_{\mathrm{P}-5^{\prime}, \mathrm{H}-5^{\prime}}=3.4 \mathrm{~Hz}, J_{\mathrm{P}-5^{\prime}, \mathrm{H}-5^{\prime \prime}}=\right.$ 3.4 Hz, P-5')

$2^{\prime}$-Diphosphoramidophosphonouridine $5^{\prime}$-Monophosphate (23): ${ }^{1} \mathrm{H}-\mathrm{NMR}$ $\left(\mathrm{D}_{2} \mathrm{O}\right) \delta: 6.02\left(1 \mathrm{H}, \mathrm{d}, J_{1^{\prime}, 2^{\prime}}=6.0 \mathrm{~Hz}, \mathrm{H}-1^{\prime}\right), 4.67\left(1 \mathrm{H}, \mathrm{ddd}, J_{1^{\prime}, 2^{\prime}}=6.0 \mathrm{~Hz}\right.$, $\left.J_{2^{\prime} 3^{\prime}}=5.5 \mathrm{~Hz}, J_{\mathrm{P}_{-\mathrm{H}-2^{\prime}}}=8.5 \mathrm{~Hz}, \mathrm{H}-2^{\prime}\right), 4.43\left(1 \mathrm{H}, \mathrm{dd}, J_{2^{\prime} 3^{\prime}}=5.5 \mathrm{~Hz}, J_{3^{\prime} 4^{\prime}}=3.5\right.$ $\left.\mathrm{Hz}, \mathrm{H}-3^{\prime}\right), 4.17^{\prime}\left(1 \mathrm{H}, \mathrm{ddd}, J_{3^{\prime}, 4^{\prime}}=3.5 \mathrm{~Hz}, J_{4^{\prime}, 5^{\prime}}=1.5 \mathrm{~Hz}, J_{4^{\prime}, 5^{\prime \prime}}=4.0 \mathrm{~Hz}, \mathrm{H}-4^{\prime}\right)$, $3.90\left(1 \mathrm{H}, \mathrm{m}, J_{4^{\prime}, 5^{\prime}}=1.5 \mathrm{~Hz}, J_{4^{\prime}, 5^{\prime \prime}}=4.0 \mathrm{~Hz}, J_{5^{\prime}, 5^{\prime \prime}}=11.5 \mathrm{~Hz}, J_{\mathrm{P}-5^{\prime}, \mathrm{H}-5^{\prime}}=3.3 \mathrm{~Hz}, \mathrm{H}-\right.$ $\left.5^{\prime}\right), 3.83\left(1 \mathrm{H}, \mathrm{m}, J_{4^{\prime}, 5^{\prime}}=1.5 \mathrm{~Hz}, J_{4^{\prime}, 5^{\prime \prime}}=4.0 \mathrm{~Hz}, J_{5^{\prime}, 5^{\prime \prime}}=11.5 \mathrm{~Hz}, J_{\mathrm{P}-5^{\prime}, \mathrm{H}-5^{\prime \prime}}=3.3\right.$ $\left.\mathrm{Hz}, \mathrm{H}-5^{\prime \prime}\right) .{ }^{31} \mathrm{P}-\mathrm{NMR}\left(\mathrm{D}_{2} \mathrm{O}\right) \delta: 0.4\left(1 \mathrm{P}, \mathrm{dd}, J_{\mathrm{P} P}=6.7 \mathrm{~Hz}, J_{\mathrm{P}-2^{\prime}}=8.5 \mathrm{~Hz}, \mathrm{P}_{\alpha}\right)$, $-9.7\left(1 \mathrm{P}, \mathrm{dd}, J_{\mathrm{P}_{\alpha} \mathrm{P}_{\beta}}=6.7 \mathrm{~Hz}, J_{\mathrm{P}_{\beta}, \mathrm{P}_{\gamma}}=20.8 \mathrm{~Hz}, \mathrm{P}_{\beta}\right),-5.3\left(1 \mathrm{P}, \mathrm{d}, J_{\mathrm{P}_{\beta}, \mathrm{P}_{\gamma}}=20.8 \mathrm{~Hz}\right.$, $\left.\mathrm{P}_{\gamma}\right), 4.2\left(1 \mathrm{P}, \mathrm{dd}, \tilde{J}_{\mathrm{P}-5^{\prime}, \mathrm{H}-5^{\prime}}=3.3 \mathrm{~Hz}, J_{\mathrm{P}-5^{\prime}, \mathrm{H}-5^{\prime \prime}}=3.3 \mathrm{~Hz}, \mathrm{P}-5^{\prime}\right)$.

3'-Diphosphoramidophosphonouridine $5{ }^{\prime}$-Monophosphate (24): ${ }^{1} \mathrm{H}-\mathrm{NMR}$ $\left(\mathrm{D}_{2} \mathrm{O}\right) \delta: 5.94\left(1 \mathrm{H}, \mathrm{d}, J_{1^{\prime}, 2^{\prime}}=6.0 \mathrm{~Hz}, \mathrm{H}-1^{\prime}\right), 4.62\left(1 \mathrm{H}, \mathrm{dd}, J_{1^{\prime}, 2^{\prime}}=6.0 \mathrm{~Hz}\right.$, $\left.J_{2^{\prime}, 3^{\prime}}=5.0 \mathrm{~Hz}, \mathrm{H}-2^{\prime}\right), 4.78\left(1 \mathrm{H}, \mathrm{ddd}, J_{2^{\prime}, 3^{\prime}}=5.0 \mathrm{~Hz}, J_{3^{\prime}, 4^{\prime}}=5.0 \mathrm{~Hz}, J_{\mathrm{P}_{\infty} \mathrm{H}-3^{\prime}}=\right.$ $\left.8.7 \mathrm{~Hz}, \mathrm{H}-3^{\prime}\right), 4.34\left(1 \mathrm{H}, \mathrm{ddd}, J_{3^{\prime}, 4^{\prime}}=5.0 \mathrm{~Hz}, J_{4^{\prime}, 5^{\prime}}=2.0 \mathrm{~Hz}, J_{4^{\prime}, 5^{\prime \prime}}=4.0 \mathrm{~Hz}, \mathrm{H}-\right.$ $\left.4^{\prime}\right), 3.93\left(1 \mathrm{H}, \mathrm{m}, J_{4^{\prime}, 5^{\prime}}=2.0 \mathrm{~Hz}, J_{4^{\prime}, 5^{\prime \prime}}=4.0 \mathrm{~Hz}, J_{5^{\prime}, 5^{\prime \prime}}=11.5 \mathrm{~Hz}, J_{\mathrm{P}-5^{\prime}, \mathrm{H}-5^{\prime}}=\right.$ $\left.3.6 \mathrm{~Hz}, \mathrm{H}-5^{\prime}\right), 3.86\left(1 \mathrm{H}, \mathrm{m}, J_{4^{\prime}, 5^{\prime}}=2.0 \mathrm{~Hz}, J_{4^{\prime}, 5^{\prime \prime}}=4.0 \mathrm{~Hz}, J_{5^{\prime}, 5^{\prime \prime}}=11.5 \mathrm{~Hz}\right.$, $\left.J_{\mathrm{P}-5^{\prime}, \mathrm{H}-5^{\prime}}=3.6 \mathrm{~Hz}, \quad \mathrm{H}-5^{\prime \prime}\right) .{ }^{31} \mathrm{P}-\mathrm{NMR} \quad\left(\mathrm{D}_{2} \mathrm{O}\right) \quad \delta: 0.8 \quad\left(1 \mathrm{P}, \quad \mathrm{dd}, \quad J_{\mathrm{P}_{\infty} \mathrm{P}_{\beta}}=6.3\right.$ $\left.\mathrm{Hz}, J_{\mathrm{P} \mathrm{H}-3^{\prime}}=8.7 \mathrm{~Hz}, \mathrm{P}_{\alpha}\right),-10.0\left(1 \mathrm{P}, \quad \mathrm{dd}, J_{\mathrm{P}_{\mathrm{P}}}=6.3 \mathrm{~Hz}, J_{\mathrm{P}_{\mathrm{P}} \mathrm{P}}=20.8 \mathrm{~Hz}\right.$,

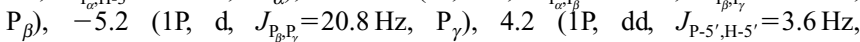
$\left.J_{\mathrm{P}-5^{\prime}, \mathrm{H}-5^{\prime \prime}}=3.6 \mathrm{~Hz}, \mathrm{P}-5^{\prime}\right)$.

Acknowledgements The authors thank Assistant Professor M. Sugiura of Kobe Pharmaceutical University for measurement of ${ }^{31} \mathrm{P}$ - and ${ }^{1} \mathrm{H}-{ }^{31} \mathrm{P} 2 \mathrm{D}$ HMBC NMR spectra. This work was partly supported by the Science Research Promotion Fund from the Japan Private School Promotion Foundation.

\section{References}

1) Hall R. H., Khorana H. G., J. Am. Chem. Soc., 77, 1871-1875 (1955).

2) Schwartz A. W., Ponnamperuma C., Nature (London), 218, 443 (1968).

3) Hulshof J., Ponnamperuma C., Origins of Life, 7, 197-224 (1976).

4) Yoshikawa M., Kato T., Takenishi T., Tetrahedron Lett., 50, 50655068 (1967).

5) Ikehara M., Otsuka E., Kakgaku No Ryoiki, 33, 566-576 (1979)

6) Ikehara M., Tanpakushitu Kakusan Khoso, 6, 615-618 (1961).

7) Hutchinson D. W., "Comprehensive Organic Chemistry," Vol. 5, ed. by Haslam E., Pergamon Press, New York, 1979, pp. 123-140.

8) Clark V. M., Kirby G. W., Todd A., J. Chem. Soc., 1497-1501 (1957).

9) Tsuhako M., Fujimoto M., Ohashi S., Nariai H., Motooka I., Bull. Chem. Soc. Jpn., 57, 3274-3280 (1984).

10) Tsuhako M., Kunitomi R., Baba Y., Miyajima T., Bull. Chem. Soc Jpn.., 64, 490-497 (1991). 
11) Tsuhako M., Nakajima A., Ohashi S., Nariai H., Motooka I., Bull. Chem. Soc. Jpn., 56, 1372-1377 (1983).

12) Inoue H., Nakayama H., Tsuhako M., Phosphorus Res. Bull., 12, 65$72(2001)$.

13) Inoue H., Watanabe M., Nakayama H., Tsuhako M., Chem. Pharm. Bull., 46, 681-683 (1998).

14) Inoue H., Nakayama H., Tsuhako M., Carbohydr. Res., 324, 10-16 (2000).

15) Inoue H., Watanabe M., Nakayama H., Tsuhako M., Chem. Pharm. Bull., 48, 802-807 (2000).

16) Inoue H., Tone N., Nakayama H., Tsuhako M., Chem. Pharm. Bull., 50, 1453-1459 (2002).

17) Inoue H., Tone N., Nakayama H., Tsuhako M., Phosphorus Res. Bull., 16, 11-18 (2003).
18) Inoue H., Tone N., Nakayama H., Tsuhako M., Carbohydr. Res., 338, 2067-2074 (2003).

19) Polland F. H., Nickless G., Warrender R. W., J. Chromatogr., 9, 493505 (1962).

20) Inoue H., Nakayama H., Tsuhako M., Maki H., Nariai H., Eguchi T., Phosphorus Res. Bull., 17, 170-173 (2004).

21) Inoue H., Nakayama H., Nariai H., Tsuhako M., Phosphorus Res. Bull., 19, 319-324 (2005).

22) Inoue H., Yamada T., Nakayama H., Tsuhako M., Chem. Pharm. Bull., 54, 1397-1402 (2006).

23) Maeda H., Nakayama H., Tsuhako M., Phosphorus Res. Bull., 21, $103-110$ (2007).

24) Sakurai M., Watanabe M., J. Mater. Sci., 29, 4897-4900 (1994). 